\title{
Phytoremediation and Microorganisms-Assisted Phytoremediation of Mercury-Contaminated Soils: Challenges and Perspectives
}

\author{
Emanuela D. Tiodar ${ }^{1,2,+}$, Cristina L. Văcar $1,2,+$ and Dorina Podar 1,2,* \\ 1 Department of Molecular Biology and Biotechnology, Babeş-Bolyai University, 1 Kogălniceanu St., \\ 400084 Cluj-Napoca, Romania; dana.tiodar@ubbcluj.ro (E.D.T.); cristina.vacar@ubbcluj.ro (C.L.V.) \\ 2 Centre for Systems Biology, Biodiversity and Bioresources (3B), Babeş-Bolyai University, 3-5 Clinicilor St., \\ 400015 Cluj-Napoca, Romania \\ * Correspondence: dorina.podar@ubbcluj.ro \\ + These authors share equal contribution.
}

\section{check for} updates

Citation: Tiodar, E.D.; Văcar, C.L.; Podar, D. Phytoremediation and Microorganisms-Assisted

Phytoremediation of

Mercury-Contaminated Soils: Challenges and Perspectives. Int. J. Environ. Res. Public Health 2021, 18 , 2435. https://doi.org/10.3390/ ijerph18052435

Academic Editors: Luís Novo and Rui S. Oliveira

Received: 22 January 2021

Accepted: 24 February 2021

Published: 2 March 2021

Publisher's Note: MDPI stays neutral with regard to jurisdictional claims in published maps and institutional affiliations.

Copyright: (c) 2021 by the authors. Licensee MDPI, Basel, Switzerland. This article is an open access article distributed under the terms and conditions of the Creative Commons Attribution (CC BY) license (https:/ / creativecommons.org/licenses/by/ $4.0 /)$.

\begin{abstract}
Mercury (Hg) pollution is a global threat to human and environmental health because of its toxicity, mobility and long-term persistence. Although costly engineering-based technologies can be used to treat heavily $\mathrm{Hg}$-contaminated areas, they are not suitable for decontaminating agricultural or extensively-polluted soils. Emerging phyto- and bioremediation strategies for decontaminating $\mathrm{Hg}$-polluted soils generally involve low investment, simple operation, and in situ application, and they are less destructive for the ecosystem. Current understanding of the uptake, translocation and sequestration of $\mathrm{Hg}$ in plants is reviewed to highlight new avenues for exploration in phytoremediation research, and different phytoremediation strategies (phytostabilization, phytoextraction and phytovolatilization) are discussed. Research aimed at identifying suitable plant species and associated-microorganisms for use in phytoremediation of $\mathrm{Hg}$-contaminated soils is also surveyed. Investigation into the potential use of transgenic plants in $\mathrm{Hg}$-phytoremediation is described. Recent research on exploiting the beneficial interactions between plants and microorganisms (bacteria and fungi) that are Hg-resistant and secrete plant growth promoting compounds is reviewed. We highlight areas where more research is required into the effective use of phytoremediation on $\mathrm{Hg}$ contaminated sites, and conclude that the approaches it offers provide considerable potential for the future.
\end{abstract}

Keywords: mercury; microbe-assisted phytoremediation; heavy metals; $\mathrm{Hg}$ reduction; plants; $\mathrm{Hg}$ hyperaccumulator; phytovolatilization; metal sequestration

\section{Introduction}

Mercury release in the environment has received considerable attention from researchers and legal entities due to its detrimental effects on human and environmental health. Awareness of its toxicity broadened in the second half of the last century, with the Minamata tragedy. Moreover, based on its frequency, toxicity, and potential for human exposure, mercury $(\mathrm{Hg})$ has been ranked 3rd in the Substance Priority List revised by the Agency for Toxic Substances and Disease Registry [1].

In biological systems, $\mathrm{Hg}$ is a non-essential element; therefore, usually, there are no dedicated pathways for its metabolization and/or excretion. As a consequence, Hg eventually bioaccumulates and biomagnifies through the food chain [2-5]. These processes are even more pronounced in the aquatic environment, where certain naturally-occurring microorganisms shift $\mathrm{Hg}$ speciation to methylmercury (MeHg), which is easily absorbed by phytoplankton, then subsequently transferred to zooplankton. It then accumulates in fish, and other longer-living species, and ultimately in humans [6-8]. Frequent consumption of $\mathrm{MeHg}$ contaminated products such as fish, shellfish, and rice, may often lead to chronic 
toxicity in humans, affecting primarily the kidneys and the central nervous system [8-14]. A diverse diet will help to avoid the accumulation of $\mathrm{Hg}$ in toxic concentrations in humans, but indigenous populations, for example in the Arctic or Amazon, which rely mainly on sea-based food supplies for their everyday nutritional needs, are extremely vulnerable to $\mathrm{Hg}$ bioaccumulation [10]. Moreover, due to its mobility in the atmosphere and the globalisation of food supplies, $\mathrm{Hg}$ is now found in many food products around the world. In a recent study on the transboundary incorporation of $\mathrm{Hg}$ through the food web, the percentage of $\mathrm{MeHg}$, of the total $\mathrm{Hg}$, biomagnified compared to soil, was found to be $13.9 \%$ in rice, $38.1 \%$ and $48.8 \%$ in herbivorous and carnivorous invertebrates respectively, and $92.1 \%$ in 10 different species of passerine vertebrates [15]. In addition to MeHg ingestion, human poisoning can occur through skin contact with inorganic $\mathrm{Hg}^{2+}$ salts or organomercurials. Acute exposure is commonly the consequence of the occupational inhalation of $\mathrm{Hg}^{0}$ vapour, or of the accidental ingestion of inorganic $\mathrm{Hg}$ salts [16-19]. Chronic exposure often results from inhalation of elemental mercury and ingestion of $\mathrm{MeHg}$, for which the minimal risk levels are evaluated at $0.0002 \mathrm{mg} \mathrm{m}^{-3}$ and $0.003 \mathrm{mg} \mathrm{kg}^{-1}$ day $^{-1}$, respectively [20]. Not only $\mathrm{Hg}$ is toxic at such low doses, but $\mathrm{Hg}$ exposure is also very subtle and cumulative $[13,14,21,22]$. The contact exposure pathway strongly relies on the high lipophilicity that both metallic and organic mercury compounds share $[18,23] . \mathrm{Hg}^{0}$ crosses cellular membranes, and upon intracellular oxidation binds to sulfhydryl, phosphoryl, carboxyl, amide, or amine groups of enzymes, leading to enzyme inactivation, protein precipitation and generalized corrosive action $[16,24,25]$. Inorganic mercury exposure represents the least common pathway for human poisoning, potentially leading to gastrointestinal lesions and renal failure [7]. Both organic and inorganic forms of $\mathrm{Hg}$ induce apoptosis, disrupt the cellular antioxidant systems, and increase cytokine release. However, there are profound differences in the toxicity mechanisms in each of these processes that are still not entirely understood [24,25].

Mercury occurs naturally in the Earth's crust from which it is steadily and continuously released into the geosphere through volcanic activity and the constant erosion of rocks. Nevertheless, the development of industrial and technological procedures has dramatically increased $\mathrm{Hg}$ mobilization since the industrial revolution. The United Nations Environment Programme recently estimated Hg emissions into the air from anthropogenic activities to be as high as 2000-2500 tonnes per year [10]. It is highly disturbing that the anthropogenic emissions of $\mathrm{Hg}$ to the air were estimated to have increased by $20 \%$ between 2010 and 2015 [10]. Atmospheric Hg emissions in 2008 were estimated as 5207 tonnes, primarily as $\mathrm{Hg}^{0}$, from natural sources, especially the oceans, and 2320 tonnes per year from anthropogenic sources, mostly from fossil fuel combustion [26]. However, the contribution from natural sources to atmospheric $\mathrm{Hg}$ pollution includes re-emission of both natural and anthropogenic emission-deposition cycles [27]. It is noteworthy that current atmospheric $\mathrm{Hg}$ concentrations are 5.5-fold to 7.6-fold higher than pre-anthropogenic values $[10,28,29]$. The primary contributors to anthropogenic $\mathrm{Hg}$ release are artisanal and small-scale gold mining (838 tonnes), cement production (233 tonnes), non-ferrous metal production (228 tonnes), and stationary combustion of coal, gas and oil activities (in total 480 tonnes) [10]. Other anthropogenic sources of $\mathrm{Hg}$ include burning of municipal and medical waste including spent batteries, thermometers and electrical products, chloralkali production, vinyl-chloride monomer production, former mining waste disposal sites, agricultural burning and the use of $\mathrm{Hg}$-containing pesticides $[10,23]$. Special mention should be made of historically contaminated sites, of which there are over 3000 worldwide associated with $\mathrm{Hg}$ mining, precious metal processing, non-ferrous metal production, and various polluted industrial sites. These sites represent long-term $\mathrm{Hg}$ sources that contribute constantly to an average release of $\mathrm{Hg}$ into the environment of 198 tonnes per year: 82 tonnes enter the atmosphere and 116 tonnes are transported by hydrological processes $[10,23,30]$.

The transboundary nature of $\mathrm{Hg}$ pollution and its severe toxicity both to humans and to the environment has required strict action to be taken to reduce usage and spread of $\mathrm{Hg}$ and to deal with its waste (United Nations Environment Programme, 3rd Conference of the 
Parties of Minamata Convention on Mercury, Nov. 2019-UNEP/MC/COP.3/INF/28). The objective of the global Minamata Convention treaty, active as of August 2017, is to protect the environment and human health from anthropogenic $\mathrm{Hg}$ and other $\mathrm{Hg}$ compounds (Minamata Convention on Mercury, 2013, Art. 1). Even though Hg usage has fallen in recent years, abandoned mines and chloralkali plants are still sources of continuous mercury pollution by producing toxic waste, vapour, or organomercurial compounds [31,32] Technologies such as chemical precipitation, extraction, adsorption, encapsulation, thermal treatment, vitrification, electro-dialysis, are conventional methods of soil and aquatic $\mathrm{Hg}$ remediation. However, these technologies are costly and laborious, alter the soil quality, may depend on certain substrate characteristics or pretreatment, and themselves generate hazardous waste that is difficult to recycle, demanding further treatment before disposal $[33,34]$. Furthermore, engineering technologies are applicable only to small-scale polluted sites, whereas $\mathrm{Hg}$ contamination often spreads as far as $50 \mathrm{~km}$ from point sources, affecting extensive inhabited and agricultural areas [35-40]. Thus, these areas cannot be treated using conventional remediation techniques. In contrast to engineering-based remediation technologies, plants can be used to treat substrates containing contaminants such as $\mathrm{Hg}$ without negatively affecting the soil and its biota. Moreover, plant-based strategies to treat contaminated substrates are relatively low in cost and maintenance compared with the engineering procedures. Moreover, plant and microorganism (fungi and bacteria) interactions at the root level (within the rhizosphere) can have synergistic beneficial effects in the remediation of heavy metal contamination in soil. Consequently, increasing interest has been given to creating and implementing combined bio- (the use of microorganisms) and phytoremediation strategies that are environmentally friendly, low in cost and unlikely to generate toxic by-products [41-47].

The ability to survive on sites with moderate contamination with heavy metals is a striking evolutionary trait shared by many plant taxa. Even more impressive is the acquired hypertolerance mechanism that allows over 700 angiosperm hyperaccumulator species to grow and thrive in extremely heavy metal contaminated substrates [48]. Mercury is particularly known for its potent phytotoxic characteristics. Yet, plant communities develop on sites that are heavily contaminated with $\mathrm{Hg}$, including active or former gold mines around the world [49-57]. Many studies have sought to identify the plant species that are best-adapted for growth on these harsh and heavily $\mathrm{Hg}$ contaminated soils and on their potential for phytoremediation. Although no hyperaccumulator plant species for $\mathrm{Hg}$ phytoremediation have been identified to date; recent research has focused on the role that rhizosphere-inhabiting microorganisms can play in assisting in the phytoremediation of $\mathrm{Hg}$ contaminated soil. The presence of $\mathrm{Hg}$ in the substrate alters the abundance and diversity of soil microbial communities towards species possessing detoxification mechanisms [58-60]. Some microorganisms, including bacteria and fungi, are able to transform $\mathrm{Hg}$ species by reducing $\mathrm{Hg}^{2+}$, degrading organomercurials, and methylating $\mathrm{Hg}^{2+}[42,47,61,62]$. Additionally, various functional groups present at the cell's surface can complex and affect $\mathrm{Hg}$ speciation and mobility. Moreover, microorganisms can secrete compounds that can be beneficial for plant growth and thus can promote plant survival in $\mathrm{Hg}$ contaminated soils. Numerous studies on bacterial Hg-resistance have focused on uncovering intracellular detoxifying mechanisms; however, research on their potential to assist phytoremediation has only recently been addressed. Understanding the interactions between plants native to $\mathrm{Hg}$ contaminated soils and their root-associate microorganisms can help to establish efficient and green $\mathrm{Hg}$ remediation strategies that could be used for the reclamation of large areas without the need for additional chemical applications or engineering technologies, therefore causing the least ecosystem interference and incurring the lowest costs.

The aim of the present work is to comprehensively review progress with respect to phytoremediation of $\mathrm{Hg}$ contaminated soils, using either plant species alone, or plant species and associated microorganisms. Previous reviews on the remediation of $\mathrm{Hg}$ contaminated soils have considered engineering-based technologies or chemical applications, 
sparingly addressing phytoremediation. In recent years, research has focused more on microorganism-assisted strategies, and although important progress has been made, approaches are often disparate. We review current knowledge of phytoremediation and microorganism remediation of $\mathrm{Hg}$-contaminated soils, and identify areas that need further study. We also describe the molecular mechanisms involved in the acquisition, sequestration, and transformation of $\mathrm{Hg}$ in plants and microorganisms in $\mathrm{Hg}$ contaminated soils.

\section{Hg Uptake and Detoxification in Plants}

Vascular plants have adopted ingenious and diverse strategies to cope with toxic concentrations of heavy metals, including $\mathrm{Hg}$. These comprise avoidance of heavy metal, thus restricting its uptake, stabilization of the metal within the root through binding and sequestration, reduced translocation to aboveground tissues, and sequestration or possible chemical $\mathrm{Hg}$ reduction within the leaves. Most terrestrial plants function as excluders with respect to nonessential elements, including $\mathrm{Hg}$. Plants can reduce metal uptake by releasing organic acid exudates such as citrate, malate, and oxalate that chelate the metal ions in the soil solution, thus reducing the bioavailability $[63,64]$. Plants limit metal uptake by manoeuvring their inner cellular metal tolerance network to set an efficient barrier against the entrance of toxic elements at the root level. To this extent, the root cell wall becomes the binding site of unwanted cations, especially of metals such as $\mathrm{Hg}$ that have a high affinity for the negative charges of the cell wall components [65-68].

The uptake pathways of $\mathrm{Hg}$ into root cells are governed by its speciation. The highly lipophilic organic mercurials have a simplified entrance into the symplast network via the root cell plasma membranes. However, the water-soluble ionic forms of mercury $\left(\mathrm{Hg}^{+}\right.$, $\mathrm{Hg}^{2+}$ ) are frequently retained by cell wall components. In the root apoplast, $\mathrm{Hg}^{2+}$ can be ligated to oxygen-containing molecules, such as organic acids [69-72] or to sulphur-rich structural proteins in the cell wall, including extensins and expansins [72]. The uptake of mineral forms of $\mathrm{Hg}$ (cinnabar and metacinnabar) has been quantified in the field in plants growing on Hg-contaminated soils, without much being known about the mechanisms employed [72]. Hg trafficking through the root tissues has been mapped in field plants of Marrubium vulgare harvested from a highly $\mathrm{Hg}$ contaminated site in Spain. $\mathrm{Hg}$ binding to thiol rich regions of the root apoplast determined a depletion of available thiol pools starting from the apical regions of the primary and secondary roots (major precipitation sites) towards the epidermis and outer layers of the cortex cells, and all the way up to the xylem vessels [72].

The symplastic uptake of $\mathrm{Hg}^{2+}$ is even less investigated and understood. To date, no precise membrane transporter involved in root $\mathrm{Hg}^{2+}$ uptake has been identified, though the active process has been inferred in Lupinus albus and Oryza sativa plants [65,73]. Based on the similarities between $\mathrm{Hg}$ and $\mathrm{Cd}$ in terms of chemical behaviour, lack of biological purpose and an indirect toxicity effect on plant cells [74], it might be possible that transmembrane metal transport proteins, inadvertently facilitating the influx of $\mathrm{Cd}$, could also be gateways for $\mathrm{Hg}$ entrance. In rice, $\mathrm{Cd}$ exploits its affinity for essential nutrient plasma membrane transporters, i.e., the natural resistance-associated macrophage protein (Nramp) and iron regulated transporter (IRT) families of proteins [75]. In the order of increased Cd uptake, OsNramp5, primarily a Mn and Fe uptake transporter, is followed by OsNramp1, OsIRT1, and OsIRT2, all defined by a preference for iron [76,77]. Competition for uptake between $\mathrm{Mn}$ and $\mathrm{Hg}$ was observed in Lupinus albus and Brassica napus upon addition of Mn to the $\mathrm{Hg}$ containing growth solution. The finding implied that $\mathrm{Mn}$ and $\mathrm{Hg}$ share affinity for the same transporters, but the particularity was only established in B. napus [78]. It was proposed that the putative B. napus $\mathrm{Mn}$ transporter saturated by $\mathrm{Hg}$ might be either a homolog of a Mn affinity protein of the Zrt, Irt-like protein (ZIP) family, or a homolog of the AtNramp1, already characterized for its affinity for Mn in Arabidopsis thaliana. On the other hand, the $\mathrm{Hg}$ influx pattern remained undisturbed in assays where $\mathrm{Cu}$ was added as interference, thereby eliminating $\mathrm{Cu}$ transporters from the list of $\mathrm{Hg}$ uptake possibilities 
for both plant species [78]. However, competitive interactions between $\mathrm{Hg}$ and $\mathrm{Cu}$ were inferred in an aquatic system. The uptake of $\mathrm{Hg}^{2+}$ in Elodea nuttallii shoots from water supplemented with $100 \mathrm{ng} \mathrm{HgCl}_{2} \mathrm{~L}^{-1}$ was inhibited by $97.2 \%$ and $80 \%$ respectively, upon addition of $\mathrm{Cu}^{+}$or $\mathrm{Cu}^{2+}$ [79].

Within the root cells, $\mathrm{Hg}^{2+}$ does not maintain a free ionic state. The high affinity that $\mathrm{Hg}^{2+}$ has for thiol groups directs it towards cysteine residues. Phytochelatins (PCs) are cysteine-rich peptides enzymatically assembled from units of glutathione (GSH) by phytochelatin synthase (PCS). Ubiquitous across the entire plant kingdom, PCs form covalent bonds with metal ions, including $\mathrm{Hg}^{2+}$. Iglesia-Turino et al. [80] have correlated the increased accumulation of $\mathrm{Hg}$ in the roots of Brassica napus with the tight binding to $\mathrm{PC}$, especially to $\mathrm{PC}_{2}$. In Brassica chinensis, the presence of the oxidized $\mathrm{Hg}-\mathrm{PC}, \mathrm{Hg}-$ $\mathrm{PC}_{3}, \mathrm{Hg}-\mathrm{PC}_{4}$ and $\mathrm{Hg}_{2}-\mathrm{PC}_{4}$ complexes was understood as the mechanism for sequestering the toxic ion, thus limiting its potential to cause oxidative stress [81]. Arabidopsis cad1-3 mutant, deficient in PCS and its products, displayed increased sensitivity to $\mathrm{Cd}, \mathrm{Hg}$, and As [82]. To complement this phenotype, a genetic construct with the wheat PCS1 gene, TaPCS1 was introduced into cad1-3 plants, expression being targeted either in the root or ectopically. Regardless of where the expression was targeted, $\mathrm{Cd}, \mathrm{Hg}$, and As sensitivities were all suppressed in the transgenic plants, with $\mathrm{Hg}$ being tolerated in concentrations of up to $10 \mu \mathrm{M} \mathrm{HgCl}_{2}$. Furthermore, the detection of PC complexes in stems and leaves of transgenic lines expressing TaPCS1 to the root alone proved that PC-chelated metals are transported in plants. However, the metal distribution in transgenic lines was only investigated for $\mathrm{Cd}$, for which the translocation rate to the aboveground organs increased linearly with its reduction in roots [82]. Strengthening these findings, the co-expression of two Escherichia coli genes, encoding for the enzymes required for GSH synthesis, i.e., glutamate cysteine ligase (GCL) and GSH synthetase (GS), improved growth on mercurycontaminated media in Arabidopsis thaliana plants compared to wild-type plants. The content of thiol molecules $\left(\mathrm{GSH}, \mathrm{PC}_{2}\right.$ and $\mathrm{PC}_{3}$ ) significantly increased in Hg-treated roots while simultaneously the $\mathrm{Hg}$ content of the above ground tissues was three-fold higher in transgenic than in wild-type lines [83].

Free or ligated, toxic or in excess, heavy metals must be sequestered away from the metabolically reactive cell cytosol, and the preferred storage organelle of the plant cell is the vacuole. The tonoplast as a lipid membrane is only semi-permeable, and highly selective for metal or metal-PC complexes due to the abundance of transmembrane transport proteins. To date, two ABC (ATP-Binding Cassette) transporters, AtABCC1 and AtABCC2 with affinity for PC-metal complexes, have been investigated for their potential involvement in $\mathrm{Cd}$ and $\mathrm{Hg}$ tolerance in A. thaliana [84]. The double knock-out mutant atabcc1 atabcc2 was hypersensitive in the presence of either $\mathrm{Cd}^{2+}$ or $\mathrm{Hg}^{2+}$, mimicking a phytotoxic behaviour comparable to the one previously reported for the AtPCS1 loss-of-function cad1-3 mutant. However, proof of the implication that these transporters are involved in metal-PC transfer from the cytosol into the vacuole has only been demonstrated for Cd-PC [84]. Thus, the definitive role of the $\mathrm{ABC}$ transporters in $\mathrm{Hg}-\mathrm{PC}$ transfer is yet to be demonstrated.

Disruption of proteins and induction of reactive oxygen species (ROS) formation are two cytotoxic side effects of $\mathrm{Hg}$ binding to the cysteine-rich motifs within proteins. Consequentially, protein misfolding, disruption of structure, replacement of essential co-factor ions and enzymatic activity inhibition occur. These lead to interference in the redox homeostasis of energy-generating cellular processes, photosynthesis and respiration $[85,86]$. The free radicals released under oxidative stress can eventually override the antioxidant defence system of the cell, and once the GSH pools are depleted and the ROS-enzymes have been overexploited or inhibited, the cycle of damaging oxidation can lead to membrane lipid peroxidation and eventually to cell death $[85,86]$. Within $24 \mathrm{~h}$ of exposure of Medicago sativa seedlings to $30 \mu \mathrm{M} \mathrm{Hg}$, cell redox homeostasis was affected, as shown by the depletion of the GSH pool, increased lipid and protein oxidation and subsequent cell necrosis [87]. Medicago sativa seedlings treated with $20 \mu \mathrm{M} \mathrm{Hg}$ displayed a 4-fold increase in malondialdehyde (MDA) content, a consequence of membrane lipid 
peroxidation. Moreover, increases in the non-protein thiol compounds and in the activity of superoxide dismutase (SOD), guaiacol peroxidase (POD), and ascorbate peroxidase (APX) are indicative of oxidative stress induced by $\mathrm{Hg}$ exposure [88]. Furthermore, plants able to tolerate higher concentrations of $\mathrm{Hg}$ in their growing media respond by increasing GSH production and the activity of the antioxidant enzymes. Thus, seedlings of Sesbania drummondii counteracted the toxicity of $50 \mathrm{mg} \mathrm{HgCl}_{2} \mathrm{~L}^{-1}$ with a $128.8 \%$ increase in GSH content, $37.2 \%$ in the GSH/GSSG (glutathione disulphide) ratio and 3.86- and 2.62-fold higher activities of SOD and APX respectively [89]. The tendency of plant tolerance attained by enhanced enzymatic and non-enzymatic antioxidant defence systems has likewise been apparent in Lycopersicon esculentum [90], Sesbania grandiflora [91] and Cyrtomium macrophyllum [53]. Moreover, overexpression of genes coding for ROS-scavenging enzymes has also been observed under $\mathrm{Hg}$ stress. In wild type $A$. thaliana seedlings, germinated on Murashige Skoog (MS) agar media with $20-40 \mu \mathrm{M} \mathrm{HgCl}_{2}$, the catalase (CAT3) was induced by a factor in the range of 2.5-5.0, followed by plastidial Cu/Zn SOD (CSD2), with an 1.5-2.5 fold increase [92]. Other components of the redox homeostasis complex system are certainly affected by $\mathrm{Hg}$, but are yet to be identified. Exposure of Pisum sativum seedlings to $5 \mu \mathrm{M} \mathrm{HgCl}_{2}$ upregulated the expression of six genes in the roots. Some of these genes are commonly involved in responses to different stresses: PsPOD peroxidase, PsNDA, a putative NADH dehydrogenase that can adjust the redox balance, PSAPSR, a putative adenosine 5-phosphosulphate (APS) reductase involved in sulphur metabolism, isoflavone $2^{\prime}$-hydroxylase $\left(\mathrm{I}^{\prime} \mathrm{H}\right)$ involved in the biosynthetic pathway of isoflavonoids and PsSAMPT that catalyses the formation of methylsalicylic acid (MeSA) and thus being involved in plant defence mechanisms against pathogens in roots [93].

There is no robust evidence for $\mathrm{Hg}^{2+}$ transport across cellular and vacuolar plant membranes. Transcriptomic and proteomic approaches are required to capture the mechanisms most likely to be involved in $\mathrm{Hg}$ metabolism. We suggest that if the experimental design covers gradual concentrations of metal, it would be expected to detect patterns that might facilitate the understanding of $\mathrm{Hg}$ transport and detoxification in plants. These mechanisms should be further confirmed by functional complementation of the corresponding knocked-out genes, to establish the grounds for a solid phytoremediation concept.

\section{Phytoremediation of Hg-Contaminated Soils}

Over $3000 \mathrm{Hg}$ polluted sites exist worldwide [94] and often mercury contamination extends up to $50 \mathrm{~km}$ from the industrial hot spot [35-40]. Moreover, high $\mathrm{Hg}$ mobility in the atmosphere facilitates its transport to agricultural lands, leading to it being deposited on formerly uncontaminated areas. Combined with the potential to further redistribute if $\mathrm{Hg}$ leaching occurs, the need for remediation of $\mathrm{Hg}$-contaminated soils is clear. In contrast to engineering-based remediation technologies, plants handle contaminants without affecting the topsoil, therefore conserving or even improving its fertility through root exudation [95], and involve low cost and low maintenance. Phytoremediation-the use of plants able to grow and develop in heavily contaminated soils-has therefore been proposed as an alternative, environmental friendly strategy for improving heavy metal-contaminated sites.

An efficient plant remediation system should result in contact with the toxic element and mediation of this interaction to favour its uptake. For most plants, avoiding toxic elements like $\mathrm{Hg}$ is their normal behaviour. Therefore, finding plants that do not avoid $\mathrm{Hg}$, or actively seek it out, is an important aspect of phytoremediation that needs to be solved. Plants generally forage for essential nutrients and can even secrete a wide range of chemicals - protons, organic acids, enzymes, phytosiderophores and proteins-to capture them $[96,97]$. In soil, Hg is largely adsorbed onto organic matter (humic and fulvic acids) or even metallic oxides, and therefore its bioavailability is sometimes low. Decreasing the $\mathrm{pH}$ of the soil solution increases mercury mobility. Different chemical chelator-assisted methods have been proposed for increasing the bioavailability of $\mathrm{Hg}$ for plants. However, these methods are not detailed herein for the current review focuses on phytoremediation using plants alone or in conjunction with microorganisms. 


\subsection{Phytoextraction}

In phytoextraction, plants act as sinks for $\mathrm{Hg}$ species, thus the requirements for suitable species to use are having extended root systems, high biomass production and strong cellular $\mathrm{Hg}$-buffering capacity. $\mathrm{Hg}^{2+}$ would be uptaken by roots and translocated to shoots where tolerance mechanisms, like chelation with thiol-compounds, vacuolar sequestration, and oxidative stress-alleviating enzymes, are stimulated. At the time of senescence, the $\mathrm{Hg}$-loaded plant material is ready for harvest and soil decontamination is achieved. Yet, the plant biomass should be treated as hazardous and accidental consumption throughout its life cycle would have to be contained otherwise it may contribute to food chain biomagnification [98]. Therefore, this strategy would require proper management and monitoring of the site, and possibly acquiring as well adequate methods for metal recovery from the contaminated biomass.

Some plants have adapted to extreme metal stress by evolving molecular tolerance mechanisms and thus behaving as accumulators or even hyperaccumulators. The definitive trait of an accumulator is its impressive capacity of safely translocating large amounts of metals, symplastically uptaken by root cells, into the aboveground organs [99]. Detoxification is mainly achieved eventually by long-term metal storage inside the vacuoles within the photosynthetically active plant tissue, the leaf mesophyll. Due to the high phytotoxicity of $\mathrm{Hg}$, there have been only a few accumulating plants registered to this date, let alone hyperaccumulators. The accumulation potential of plant species naturally colonizing metalliferous sites is worth exploring both for assessing its on-site phytoremediation appropriateness and for elucidating the entryways of toxic metals into the human diet.

In the search for $\mathrm{Hg}$ (hyper)accumulator plant species, analysis of native vegetation on Hg-contaminated sites has been undertaken and the results of these studies are summarised in Table 2. The highly desirable phytoremediation potential of $\mathrm{Hg}$ accumulating plants has also paved the way for studies aimed at disentangling the underlying mechanisms of plant $\mathrm{Hg}$ tolerance. However, a deep understanding of the molecular and structural aspects of $\mathrm{Hg}$ accumulation and tolerance in plants is still lacking. Most studies have focused on $\mathrm{Hg}$ accumulation by plants, rather than the molecular mechanisms involved (Table 2). In attempting to identify candidate plant species for $\mathrm{Hg}$ removal, (hyper)accumulators that are known to tolerate other metals, have been assayed for their capacity to bioaccumulate $\mathrm{Hg}$ (Table 2). As the cycle of $\mathrm{Hg}$ within the environment is very dynamic, inland waters are often contaminated. Thus, aquatic plant species have been considered for their potential for $\mathrm{Hg}$ decontamination in water. Myriophyllum aquaticum, Ludwigina palustris and Mentha aquatica achieved an average Hg removal efficiency of $99.8 \%$ when grown in water contaminated with up to $0.5 \mathrm{mg} \mathrm{Hg} \mathrm{L}^{-1}$ [100]. Investigation of the $\mathrm{Hg}$ accumulation potential of Eichornia crassipes, Pistia stratiotes, Scirpus tabernaemontani, and Colocasia esculenta in water containing 0.5 or $2 \mathrm{mg} \mathrm{Hg} \mathrm{L}^{-1}$, attested that all four plant species decreased the water $\mathrm{Hg}$ concentration after 30 days to nontoxic levels, based on Microtox analyses [101]. Moreover, Pistia stratiotes was able to accumulate quantities of up to $83.2 \mathrm{mg} \mathrm{Hg} \mathrm{kg}^{-1} \mathrm{dw}$ [101]. 


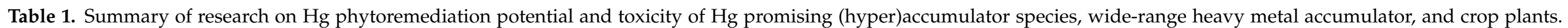

* (Growth parameters recorded in regard to the control treatments).

\begin{tabular}{|c|c|c|c|c|c|c|}
\hline Type & Plant sp. & Growth Conditions & $\begin{array}{l}\text { Phytotoxic } \\
\text { Concentration }\end{array}$ & $\begin{array}{l}\text { Growth Parameters } \\
\text { (Phytotox. Conc.) * }\end{array}$ & $\begin{array}{l}\text { Hg Accumulation } \\
\text { (BAF, BCF and TF) }\end{array}$ & References \\
\hline \multirow{9}{*}{$\begin{array}{l}\text { potential } \mathrm{Hg} \\
\text { (hyper)accumulator } \\
\text { native species }\end{array}$} & $\begin{array}{l}\text { Vigna unguiculata L. } \\
\text { Walp }\end{array}$ & $\begin{array}{l}\text { Soil pots- }-3 \text { m old ecotypes: } \\
\text { 1. native genotype } \\
\text { 2. commercial line L- } 019 \\
\text { 3. commercial line L- } 042\end{array}$ & $\begin{array}{l}5 \text { and } 8 \mathrm{mg} \mathrm{kg}^{-1} \\
\mathrm{Hg}\left(\mathrm{NO}_{3}\right)_{2} \text { (added to } \\
0.2 \mathrm{mg} \mathrm{Hg} \mathrm{kg}^{-1} \\
\text { contaminated soil) }\end{array}$ & $\begin{array}{l}\text { Negligible biomass } \\
\text { decrease with ^ } \mathrm{Hg}\end{array}$ & $\begin{array}{l}\text { root }>\text { leaf }>\text { stem; } \\
\mathrm{BCF}<1 \text { (all genotypes); } \\
\mathrm{BAF}_{\text {stem } / \text { soil }}<0.5 \\
\mathrm{BAF}_{\text {seed }} \text { soil }<0.5 ; \\
1 . \mathrm{TF}<1 \text { for native genotype } \\
2 . \mathrm{TF} 1.5 \text { (for } \\
0.2 \mathrm{mg} \mathrm{Hg} \mathrm{kg}{ }^{-1} \mathrm{dw} \text { ) for both } \\
\text { commercial lines }\end{array}$ & [102] \\
\hline & Phragmites australis & \multirow{6}{*}{$\begin{array}{l}\text { Plant samples were taken from gold } \\
\text { mine contaminated wetland (wet and } \\
\text { dry season) }\end{array}$} & \multirow{6}{*}{-} & \multirow{6}{*}{-} & $\begin{array}{l}\operatorname{root}[\mathrm{Hg}]-806 \mu \mathrm{g} \mathrm{kg}^{-1} \mathrm{dw} \\
\text { stem[Hg]_495 } \mathrm{g} \mathrm{kg}^{-1} \mathrm{dw} \\
\text { leaves[Hg]—_33 } \mathrm{g} \mathrm{kg}^{-1} \mathrm{dw} \\
\text { BAF_0.73/0.22 } \\
\mathrm{TF}-0.57 / 1.99\end{array}$ & \multirow{6}{*}[55]{} \\
\hline & Cyperus eragrostis & & & & $\begin{array}{l}\text { BAF-0.22/0.35 } \\
\text { TF-1.99/3/60 }\end{array}$ & \\
\hline & Datura stramonium & & & & $\begin{array}{l}\text { BAF-0.20/0.61 } \\
\text { TF-4.26/8.30 }\end{array}$ & \\
\hline & Panicum coloratum & & & & $\begin{array}{l}\text { BAF-0.11/0.13 } \\
\text { TF-3.70/10.94 }\end{array}$ & \\
\hline & $\begin{array}{l}\text { Persicaria } \\
\text { lapathifolia }\end{array}$ & & & & $\begin{array}{l}\mathrm{BAF}-0.11 / 0.20 \\
\mathrm{TF}-3.10 / 3.07\end{array}$ & \\
\hline & Melilotus alba & & & & $\begin{array}{l}\mathrm{BAF}-0.13 / 0.21 \\
\mathrm{TF}-0.54 / 0.60\end{array}$ & \\
\hline & Lathyrus pratensis & \multirow{2}{*}{$\begin{array}{l}\text { Aerial parts of plants growing in the } \\
\text { area of an abandoned gold mine in the } \\
\text { Czech Republic were collected } \\
\left(0.207-15.0 \mathrm{mg}^{-1} \text { total } \mathrm{Hg} \mathrm{kg}^{-1} \text { soil) }\right.\end{array}$} & \multirow{2}{*}{-} & \multirow{2}{*}{-} & Shoot $[\mathrm{Hg}]-0.108 \mathrm{mg} \mathrm{kg}^{-1} \mathrm{dw}$ & \multirow{2}{*}[54]{} \\
\hline & Epipactis sp. & & & & Shoot $[\mathrm{Hg}]-0.152 \mathrm{mg} \mathrm{kg}^{-1} \mathrm{dw}$ & \\
\hline
\end{tabular}




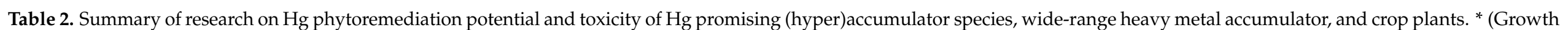
parameters recorded in regard to the control treatments).

\begin{tabular}{|c|c|c|c|c|c|c|}
\hline Type & Plant sp. & Growth Conditions & $\begin{array}{l}\text { Phytotoxic } \\
\text { Concentration }\end{array}$ & $\begin{array}{l}\text { Growth Parameters } \\
\text { (Phytotox. Conc.) * }\end{array}$ & $\begin{array}{l}\text { Hg Accumulation } \\
\text { (BAF, BCF and TF) }\end{array}$ & References \\
\hline & $\begin{array}{l}\text { Axonopus } \\
\text { compressus }\end{array}$ & \multirow{3}{*}{$\begin{array}{l}\text { Plant samples were taken from soil } \\
\text { contaminated by artisanal small-scale } \\
\text { gold mines (arbuscular mycorrhizal } \\
\text { fungi (AMF) colonization was aslo } \\
\text { determined }\end{array}$} & \multirow{3}{*}{-} & \multirow{3}{*}{-} & $\begin{array}{l}\operatorname{root}[\mathrm{Hg}]-0.15 \mathrm{mg} \mathrm{kg}^{-1} \mathrm{dw} \\
\text { shoot}[\mathrm{Hg}] \_0.33 \mathrm{mg} \mathrm{kg}^{-1} \mathrm{dw} \\
\mathrm{BAF}_{\text {root }} / \text { leaves}-0.03 / 0.06 \\
\mathrm{TF}-2.16\end{array}$ & \multirow{3}{*}{ [103] } \\
\hline & Erato polymnioides & & & & $\begin{array}{l}\operatorname{root}[\mathrm{Hg}]-3.56 \mathrm{mg} \mathrm{kg}^{-1} \mathrm{dw} \\
\text { shoot}[\mathrm{Hg}]-1.48 \mathrm{mg} \mathrm{kg}^{-1} \mathrm{dw} \\
\text { BAFroot }-0.80 ; \mathrm{TF}-0.42\end{array}$ & \\
\hline & Miconia zamorensis & & & & $\begin{array}{l}\operatorname{root}[\mathrm{Hg}]-2.06 \mathrm{mg} \mathrm{kg}^{-1} \mathrm{dw} \\
\text { shoot}[\mathrm{Hg}] \_0.98 \mathrm{mg} \mathrm{kg}^{-1} \mathrm{dw} \\
\text { BAF }_{\text {root }}-0.47 ; \mathrm{TF}-0.47\end{array}$ & \\
\hline & $\begin{array}{l}\text { Cyrtomium } \\
\text { macrophyllum }\end{array}$ & $\begin{array}{l}60 \mathrm{~d} \text { old seedlings from } \\
\text { uncontaminated sites (grown 1st } \\
\text { hydroponically) } \\
\text { 1. } 225.73 \mathrm{mg} \text { total } \mathrm{Hg} \mathrm{kg}^{-1} \text { soil or } \\
\text { 2. } 0,5,10,20,50,100,200,500 \text { and } \\
1000 \mathrm{mg} \mathrm{HgCl}_{2} \mathrm{~kg}^{-1} \text { soil }\end{array}$ & $\begin{array}{l}500 \text { and } \\
1000 \mathrm{mg} \mathrm{kg}^{-1} \mathrm{HgCl}_{2}\end{array}$ & $20.2 \%$ biomass reduction & $\begin{array}{l}\text { 1. shoot }[\mathrm{Hg}]-36.44 \mathrm{mg} \mathrm{kg}^{-1} \mathrm{dw} \\
\text { root }[\mathrm{Hg}]-13.90 \mathrm{mg} \mathrm{kg}^{-1} \mathrm{dw} \\
\text { BCF-0.061; TF-2.62 } \\
\text { 2. for treatments up to } \\
200 \mathrm{mg} \mathrm{kg}^{-1} \text { : BCF > } 1 \text {; TF > } 1\end{array}$ & [53] \\
\hline & $\begin{array}{l}\text { Manihot esculenta } \\
\text { Crantz }\end{array}$ & $\begin{array}{l}\text { 1. soil pots with mixtures of mine } \\
\text { tailings and biosolids; } 4 \mathrm{w} \text { old cuttings } \\
\text { ( } 11.67 \mathrm{mg} \text { total } \mathrm{Hg} \mathrm{kg}^{-1} \text { mine tailings); } \\
\text { 2. hydroponic solution with } 50 \text { or } \\
100 \mu \mathrm{M} \mathrm{HgCl} \mathrm{Hg}_{2} ; 5 \mathrm{w} \text { old plants }\end{array}$ & $\begin{array}{l}\text { mixtures with } 50,75 \text {, or } \\
100 \% \text { mine tailings }\end{array}$ & $\begin{array}{l}\text { significant root biomass } \\
\text { decrease }\end{array}$ & $\begin{array}{l}\text { 1. } \mathrm{Hg} \text { not determined in plants } \\
\text { 2. root }[\mathrm{Hg}]-6.836 \text { and } \\
12.13 \mathrm{~g} \mathrm{~kg}^{-1} \mathrm{dw}(50 \text { and } \\
100 \mu \mathrm{M} \mathrm{Hg})\end{array}$ & [104] \\
\hline & Dillenia suffruticosa & \multirow{7}{*}{$\begin{array}{l}\text { Plants were cultivated on } 2 \text { ex-gold } \\
\text { mine tailings areas: } \\
\text { (i) tailings site where last mining } \\
\text { activity was } 2 \text { years prior } \\
\left(0.5 \mathrm{mg} \mathrm{Hg} \mathrm{kg}^{-1}\right) \\
\text { (ii) tailings site where last mining } \\
\text { activity was } 10 \text { years prior } \\
\left(0.02 \mathrm{mg} \mathrm{Hg} \mathrm{kg}^{-1}\right)\end{array}$} & \multirow{7}{*}{ none observed } & \multirow{7}{*}{$\begin{array}{l}\text { no significant decrease in } \\
\text { plant growth (height and } \\
\text { diameter) }\end{array}$} & $\mathrm{BCF}-15.5 ; \mathrm{TF}-3.0$ & \multirow{7}{*}[50]{} \\
\hline & Vitex pinnata & & & & $\mathrm{BCF}-40 ; \mathrm{TF}-0.6$ & \\
\hline & $\begin{array}{l}\text { Archidendron } \\
\text { pauciflorum }\end{array}$ & & & & $\mathrm{BCF}-11.0 ; \mathrm{TF}-0.1$ & \\
\hline & $\begin{array}{l}\text { Anacardium } \\
\text { occidentale }\end{array}$ & & & & $\mathrm{BCF}-6.5 ; \mathrm{TF}-0.3$ & \\
\hline & Shorea leprosula & & & & $\mathrm{BCF}-7.5 ; \mathrm{TF}-0.5$ & \\
\hline & Alstonia scholaris & & & & $\mathrm{BCF}-45.0 ; \mathrm{TF}-1.3$ & \\
\hline & Hevea brasiliensis & & & & $\mathrm{BCF}-13.5 ; \mathrm{TF}-0.1$ & \\
\hline
\end{tabular}


Table 2. Cont.

\begin{tabular}{|c|c|c|c|c|c|c|}
\hline Type & Plant sp. & Growth Conditions & Phytotoxic Concentration & $\begin{array}{l}\text { Growth Parameters } \\
\text { (Phytotox. Conc.) * }\end{array}$ & $\begin{array}{l}\text { Hg Accumulation } \\
\text { (BAF, BCF and TF) }\end{array}$ & References \\
\hline & Alyssum saxatile $\mathrm{L}$. & \multirow{11}{*}{$\begin{array}{l}\text { Plant samples were collected from } 41 \text { sites in } \\
\text { an active mining district in Western Turkey } \\
\text { (mean } 6.609 \mu \mathrm{g} \mathrm{Hg} \mathrm{kg}{ }^{-1} \text { soil) }\end{array}$} & \multirow{11}{*}{-} & \multirow{11}{*}{ 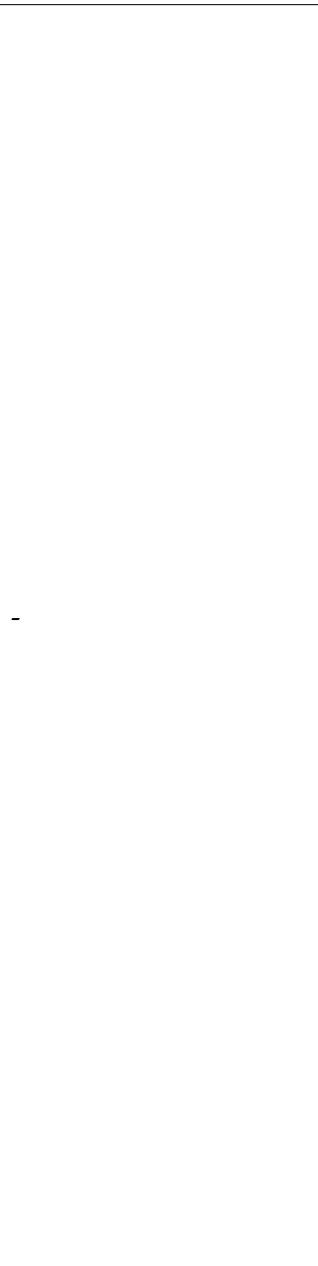 } & $\begin{array}{l}\operatorname{root}[\mathrm{Hg}] / \text { soil }[\mathrm{Hg}]-0.10 \\
\text { shoot }[\mathrm{Hg}] / \text { soil }[\mathrm{Hg}] \longrightarrow 0.04 \\
\text { Mean } \mathrm{TF}-0.85\end{array}$ & \multirow{11}{*}{ [52] } \\
\hline & Anchusa arvensis $\mathrm{L}$. & & & & $\begin{array}{l}\operatorname{root}[\mathrm{Hg}] / \text { soil }[\mathrm{Hg}]-0.06 \\
\text { shoot }[\mathrm{Hg}] / \text { soil }[\mathrm{Hg}]-0.06 \\
\text { Mean } \mathrm{TF}-1.03\end{array}$ & \\
\hline & Centaurea cyanus L. & & & & $\begin{array}{l}\operatorname{root}[\mathrm{Hg}] / \text { soil }[\mathrm{Hg}]<0.5 \\
\text { shoot }[\mathrm{Hg}] / \text { soil }[\mathrm{Hg}]<0.5 \\
\text { Mean } \mathrm{TF}>1\end{array}$ & \\
\hline & Cynoglossum officinale & & & & $\begin{array}{l}\operatorname{root}[\mathrm{Hg}] / \text { soil }[\mathrm{Hg}]<1 \\
\text { shoot }[\mathrm{Hg}] / \text { soill }[\mathrm{Hg}]<1 \\
\text { Mean } \mathrm{TF}<1\end{array}$ & \\
\hline & Glaucium flavum & & & & $\begin{array}{l}\operatorname{root}[\mathrm{Hg}] / \text { soil }[\mathrm{Hg}]-0.09 \\
\text { shoot }[\mathrm{Hg}] / \text { soil }[\mathrm{Hg}] \longrightarrow 0.02 \\
\text { Mean } \mathrm{TF}-0.25\end{array}$ & \\
\hline & Isatis sp. L. & & & & $\begin{array}{l}\operatorname{root}[\mathrm{Hg}] / \text { soil }[\mathrm{Hg}]-0.02 \\
\text { shoot }[\mathrm{Hg}] / \text { soil }[\mathrm{Hg}] \longrightarrow 0.02 \\
\text { Mean } \mathrm{TF}-0.63\end{array}$ & \\
\hline & Onosma sp. & & & & $\begin{array}{l}\operatorname{root}[\mathrm{Hg}] / \text { soil }[\mathrm{Hg}]<0.5 \\
\text { shoot }[\mathrm{Hg}] / \text { soil }[\mathrm{Hg}]<0.5 \\
\text { Mean } \mathrm{TF}>1\end{array}$ & \\
\hline & Phlomis sp. & & & & $\begin{array}{l}\operatorname{root}[\mathrm{Hg}] / \text { soill[Hg] }-0.21 \\
\text { shoot }[\mathrm{Hg}] / \text { soil }[\mathrm{Hg}]-0.56 \\
\text { Mean } \mathrm{TF}-2.05\end{array}$ & \\
\hline & Silene compacta & & & & $\begin{array}{l}\operatorname{root}[\mathrm{Hg}] / \text { soil }[\mathrm{Hg}]<0.5 \\
\text { shoot }[\mathrm{Hg}] / \text { soil }[\mathrm{Hg}]<0.5 \\
\text { Mean } \mathrm{TF}-1.66\end{array}$ & \\
\hline & $\begin{array}{l}\text { Tripleurospermum } \\
\text { maritimum }\end{array}$ & & & & $\begin{array}{l}\operatorname{root}[\mathrm{Hg}] / \text { soil }[\mathrm{Hg}]-0.02 \\
\text { shoot }[\mathrm{Hg}] / \text { soil }[\mathrm{Hg}] \longrightarrow 0.01 \\
\text { Mean } \mathrm{TF}-0.59\end{array}$ & \\
\hline & Verbascum thapsus L. & & & & $\begin{array}{l}\operatorname{root}[\mathrm{Hg}] / \text { soil }[\mathrm{Hg}]-0.03 \\
\text { shoot }[\mathrm{Hg}] / \text { soil }[\mathrm{Hg}] \longrightarrow 0.06 \\
\text { Mean } \mathrm{TF}-2.47\end{array}$ & \\
\hline & Sesbania grandiflora & $17 \mathrm{~d}$ old seedlings in hydroponic solution & 50 and $60 \mathrm{mg} \mathrm{L}^{-1} \mathrm{HgCl}_{2}$ & $\begin{array}{l}56 \% \text { growth decrease } \\
19 \% \text { biomass reduction } \\
\left(60 \mathrm{mg} \mathrm{Hg} \mathrm{L}^{-1}\right)\end{array}$ & $\begin{array}{l}\text { mostly in roots; } \\
\text { TF-low. }\end{array}$ & [91] \\
\hline
\end{tabular}


Table 2. Cont

\begin{tabular}{|c|c|c|c|c|c|c|}
\hline Type & Plant sp. & Growth Conditions & $\begin{array}{l}\text { Phytotoxic } \\
\text { Concentration }\end{array}$ & $\begin{array}{l}\text { Growth Parameters } \\
\text { (Phytotox. Conc.)* }\end{array}$ & $\begin{array}{l}\text { Hg Accumulation } \\
\text { (BAF, BCF and TF) }\end{array}$ & References \\
\hline & Jatropha curcas & $\begin{array}{l}\text { Pots with } \mathrm{Hg} \text {-contaminated soil } \\
\left(1.76 \mathrm{mg} \mathrm{kg}{ }^{-1}\right) \text { spiked with } 1,5 \text { or } \\
10 \mathrm{mg} \mathrm{Hg}\left(\mathrm{NO}_{3}\right)_{2} \mathrm{~kg}^{-1} ; 1,2,3 \text { or } 4 \mathrm{~m} \\
\text { old seedlings (seeds of plants from } \\
\text { uncontaminated soil) }\end{array}$ & none observed & - & $\begin{array}{l}\text { plant }[\mathrm{Hg}]-\max . \\
7.25 \mathrm{mg} \mathrm{kg}^{-1} \mathrm{dw} \text { (for } \\
10 \mathrm{mg} \mathrm{Hg} \mathrm{kg}^{-1} \text { soil) } \\
\text { BCF-good, with increased } \\
\text { exposure (4th month); } \\
\text { TF } 1 \text { (after } 2 \text { months, then } \\
\text { decreased) }\end{array}$ & [105] \\
\hline & Lepidium sativum $\mathrm{L}$. & $\begin{array}{l}\text { Soil pots (spiked with } 10 \text { or } \\
100 \mathrm{mg} \mathrm{HgCl} \mathrm{kg}^{-1} \mathrm{dw} \text { ) with/without } \\
\text { different fractions of uncontaminated } \\
\text { compost; } 10 \mathrm{~d} \text { seedlings }\end{array}$ & $\begin{array}{l}\text { (a) } 10 \text { and } \\
100 \mathrm{mg} \mathrm{kg}^{-1} \mathrm{HgCl}_{2} \text {; } \\
\text { (b) none observed for } \\
\text { compost amended soil }\end{array}$ & $\begin{array}{l}\text { (a) } 27 \% \text { decrease in shoot } \\
\text { length; } 53 \% \text { decrease in } \\
\text { root } \\
\left(10 \mathrm{mg} \mathrm{Hg} \mathrm{kg}^{-1}\right)\end{array}$ & $\begin{array}{l}\text { mostly in roots; } \\
\text { add. compost— accumulation; } \\
\text { BCF-high for } \\
10 \mathrm{mg} \mathrm{Hg} \mathrm{kg}^{-1} \mathrm{dw} \text { in } 2 / 1 \\
\text { compost }\end{array}$ & [106] \\
\hline & $\begin{array}{l}\text { Flueggea tinctoria (L.) } \\
\text { G.L. Webster }\end{array}$ & \multirow{5}{*}{$\begin{array}{l}\text { Aerial plant parts were collected from a } \\
\text { riparian area in the mining district of } \\
\text { Almadén }\left(122-385 \mathrm{mg} \text { total } \mathrm{Hg} \mathrm{kg}^{-1}\right. \\
\text { soil) }\end{array}$} & \multirow{5}{*}{-} & \multirow{5}{*}{-} & BCF-5.9 & \multirow{5}{*}{ [49] } \\
\hline & $\begin{array}{l}\text { Tamarix canariensis } \\
\text { Willd. }\end{array}$ & & & & BCF-10.72 & \\
\hline & Nerium oleander L. & & & & BCF- 6.2 & \\
\hline & $\begin{array}{l}\text { Typha domingensis } \\
\text { Pers. }\end{array}$ & & & & $\mathrm{BCF}-4.3$ & \\
\hline & $\begin{array}{l}\text { Phragmites australis } \\
\text { Cav. }\end{array}$ & & & & $\mathrm{BCF}-32.2$ & \\
\hline & Atriplex conodocarpa & \multirow{2}{*}{$\begin{array}{l}25 \text { seeds / species were sown in pots } \\
\text { with } \mathrm{Hg} \text { spiked potting mix } \\
\left(17.3 \mathrm{mg} \mathrm{Hg} \mathrm{kg}^{-1} \text { soil }\right)\end{array}$} & \multirow{2}{*}{$\begin{array}{l}\text { no phytotoxic symptoms } \\
\text { were observed }\end{array}$} & \multirow{2}{*}{$\begin{array}{l}\text { Biomass, leaf area and } \\
\text { number remained } \\
\text { unchanged (in regards to } \\
\text { unspiked soil) }\end{array}$} & $\begin{array}{l}\text { shoot }[\mathrm{Hg}]-1.09 \mathrm{mg} \mathrm{kg}^{-1} \mathrm{dw} \\
\text { translocation } \%-19 \%\end{array}$ & \multirow{2}{*}{ [107] } \\
\hline & $\begin{array}{l}\text { Australodanthonia } \\
\text { caespitose }\end{array}$ & & & & $\begin{array}{l}\text { shoot }[\mathrm{Hg}]-1.20 \mathrm{mg} \mathrm{kg}^{-1} \mathrm{dw} \\
\text { translocation-15.9\% }\end{array}$ & \\
\hline & Chilopsis linearis & $2 \mathrm{w}$ old seedlings in Hoagland solution & $\begin{array}{l}50,100,200 \mu \mathrm{M} \\
\left(\mathrm{CH}_{3} \mathrm{COO}\right)_{2} \mathrm{Hg}\end{array}$ & $\begin{array}{l}49 \% \text { decrease in root } \\
\text { length }\end{array}$ & $\begin{array}{l}\operatorname{root}[\mathrm{Hg}]-\wedge \text { with } \mathrm{Hg} \text { conc. } \\
\mathrm{TF}-\mathrm{low}\end{array}$ & [108] \\
\hline & Medicago sativa & $\begin{array}{l}4 \mathrm{~d} \text { old seedlings in } 1 / 4 \text { Hoagland } \\
\text { solution }\end{array}$ & $20 \mu \mathrm{M} \mathrm{HgCl}_{2}$ & $\begin{array}{l}54 \% \text { decrease in root } \\
\text { biomass }\end{array}$ & - & [88] \\
\hline
\end{tabular}


Table 2. Cont.

\begin{tabular}{|c|c|c|c|c|c|c|}
\hline Type & Plant sp. & Growth Conditions & $\begin{array}{l}\text { Phytotoxic } \\
\text { Concentration }\end{array}$ & $\begin{array}{l}\text { Growth Parameters } \\
\text { (Phytotox. Conc.) * }\end{array}$ & $\begin{array}{l}\text { Hg Accumulation } \\
\text { (BAF, BCF and TF) }\end{array}$ & References \\
\hline & Eichornia crassipes & \multirow{4}{*}{$\begin{array}{l}30 \mathrm{~d} \text { old plants in spring water tanks }(0, \\
\left.0.5,2 \mathrm{mg} \mathrm{L}^{-1} \mathrm{HgSO}_{4}\right)\end{array}$} & \multirow{4}{*}{-} & \multirow{4}{*}{-} & $\begin{array}{l}\operatorname{root}[\mathrm{Hg}]-26.2 \mathrm{mg} \mathrm{kg}^{-1} \mathrm{dw} \\
\text { (for } 2 \mathrm{mg} \mathrm{Hg} \mathrm{L}^{-1} \text { ) }\end{array}$ & \multirow{4}{*}{ [101] } \\
\hline & Pistia stratiotes & & & & $\operatorname{root}[\mathrm{Hg}]-83.2 \mathrm{mg} \mathrm{kg}^{-1} \mathrm{dw}$ & \\
\hline & $\begin{array}{l}\text { Scirpus } \\
\text { tabernaemontani }\end{array}$ & & & & $\operatorname{root}[\mathrm{Hg}]-3.88 \mathrm{mg} \mathrm{kg}^{-1} \mathrm{dw}$ & \\
\hline & Colocasia esculenta & & & & $\operatorname{root}[\mathrm{Hg}]-6.99 \mathrm{mg} \mathrm{kg}^{-1} \mathrm{dw}$ & \\
\hline & $\begin{array}{l}\text { Sesbania } \\
\text { drummondii }\end{array}$ & $\begin{array}{l}15 \mathrm{~d} \text { old seedlings in } 1 / 2 \text { Hoagland } \\
\text { solution }\end{array}$ & $\begin{array}{l}50 \text { and } 100 \mathrm{mg} \mathrm{L}^{-1} \\
\mathrm{HgCl}_{2}\end{array}$ & $\begin{array}{l}36.8 \% \text { biomass reduction } \\
\left(100 \mathrm{mg} \mathrm{Hg} \mathrm{L}^{-1}\right)\end{array}$ & $\operatorname{root}[\mathrm{Hg}]>\operatorname{shoot}[\mathrm{Hg}]$ & [89] \\
\hline & Rumex induratus & $\begin{array}{l}\text { Field experiment; } \\
\text { Whole plants were collected from sites } \\
\text { with: } \\
122.4 \mathrm{mg} \text { total } \mathrm{Hg} \mathrm{kg}^{-1} \mathrm{dw}(0.006 \% \\
\text { available } \mathrm{Hg})\end{array}$ & & & $\begin{array}{l}\operatorname{root}[\mathrm{Hg}]-8.3 \mathrm{mg} \mathrm{kg}^{-1} \mathrm{dw} \\
\text { shoot }[\mathrm{Hg}]-7.3 \mathrm{mg} \mathrm{kg}^{-1} \mathrm{dw} \\
\mathrm{TF}-0.96 \\
\text { Phytoextraction efficiency } \\
12.9 \mathrm{~g} \mathrm{Hg} \mathrm{ha}^{-1} \text { year }^{-1}\end{array}$ & \multirow{2}{*}{ [109] } \\
\hline & Marrubium vulgare & $\begin{array}{l}550.1 \mathrm{mg} \text { total } \mathrm{Hg} \mathrm{kg}^{-1} \mathrm{dw}(0.032 \% \\
\text { available) }\end{array}$ & & & $\begin{array}{l}\operatorname{root}[\mathrm{Hg}]-67.2 \mathrm{mg} \mathrm{kg}^{-1} \mathrm{dw} \\
\text { shoot}[\mathrm{Hg}]-23.0 \mathrm{mg} \mathrm{kg}^{-1} \mathrm{dw} \\
\text { TF-0.34 } \\
\text { Phytoextraction efficiency } \\
27.6 \mathrm{~g} \mathrm{Hg} \mathrm{ha}^{-1} \text { year }^{-1}\end{array}$ & \\
\hline & Medicago sativa & $\begin{array}{l}12 \mathrm{~d} \text { old seedlings in a beaker-size } \\
\text { hydroponic system }\end{array}$ & $30 \mu \mathrm{M} \mathrm{HgCl}{ }_{2}$ & $\begin{array}{l}\text { abrupt } 30-40 \% \text { growth } \\
\text { inhibition (first } 24 \mathrm{~h} \text { ) }\end{array}$ & - & [87] \\
\hline & $\begin{array}{l}\text { Myriophylhum } \\
\text { aquaticum } \\
\text { Ludwigina palustris } \\
\text { Mentha aquatica }\end{array}$ & $\begin{array}{l}21 \mathrm{~d} \text { old plants in water solution with } \\
\text { hydroponic fertilizer }\end{array}$ & - & - & $\begin{array}{l}\text { average removal } \\
\text { efficiency-99.8\% (all } 3 \text { plants); } \\
\text { removal rate- } 0.0787- \\
0.0002 \mathrm{mg} \mathrm{Hg} \mathrm{L}^{-1} \mathrm{~d}^{-1}\end{array}$ & {$[100]$} \\
\hline & Nicotiana miersii & $5 \mathrm{w}$ old plants in $1 / 4$ Hoagland & $\begin{array}{l}\text { 1. } 1.0 \mathrm{mg} \mathrm{Hg}^{0} \mathrm{~m}^{3} \\
\text { 2. } 1.0 \mu \mathrm{g} \mathrm{HgCl}_{2} \mathrm{~mL}^{-1}\end{array}$ & $\begin{array}{l}\text { 1. Visible signs of stress } \\
\text { 2. Inhibition of root and } \\
\text { shoot }\end{array}$ & $\begin{array}{l}\text { 1. only in shoots } \\
\text { 2. mostly in roots }\end{array}$ & [110] \\
\hline
\end{tabular}


Table 2. Cont.

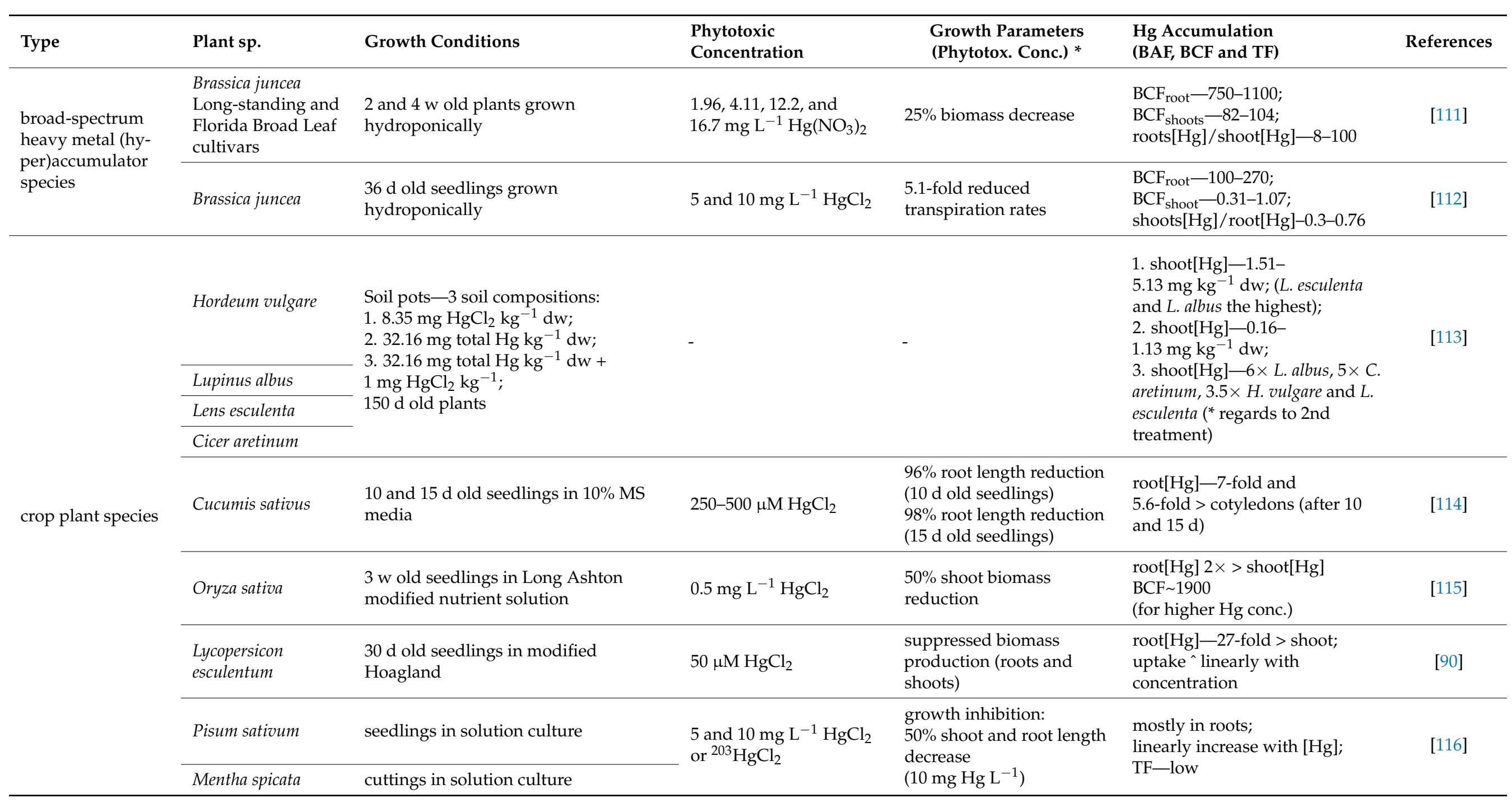

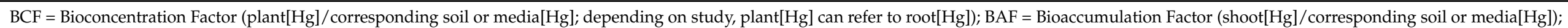

$\mathrm{TF}=$ Translocation Factor $(\operatorname{shoot}[\mathrm{Hg}] / \operatorname{root}[\mathrm{Hg}]) ;^{\wedge}=$ increase; $\mathrm{d}=$ days; $\mathrm{w}=$ weeks; $\mathrm{m}=$ months; $[\mathrm{Hg}]=\mathrm{Hg}$ concentration. 
In an attempt to find more efficient plant species for metal extraction, studies have been conducted on crop plants that already have highly organized cultivation and harvest technologies. Rodriguez et al. [113] investigated the $\mathrm{Hg}$ shoot accumulation in barley, white lupine, lentil, chickpea, and wheat grown in substrates with $\mathrm{Hg}$ present either naturally bound to soil constituents or in soluble form. When grown in pots with contaminated soil originating from the Almadén region of Spain $\left(32.16 \mathrm{mg} \mathrm{kg}^{-1} \mathrm{dw}\right)$, plants were not able to accumulate $\mathrm{Hg}$ in proportion to its concentration in the soil. Small concentrations of $\mathrm{Hg}$ $\left(0.16-1.13 \mathrm{mg} \mathrm{kg}^{-1} \mathrm{dw}\right)$ were detected in the above ground tissues, suggesting that crop plants can only take up the soluble fraction of $\mathrm{Hg}$ from the topsoil, leaving the $\mathrm{Hg}$ bound to sulphur practically undisturbed.

Accumulation of $\mathrm{Hg}$ in plant species used as fodder or for human consumption has been examined because of the high risk they pose to animal and human health. Agricultural plant species cultivated on, or close to $\mathrm{Hg}$ contaminated soils, often concentrate alarming levels of $\mathrm{Hg}$ within edible tissues, thus posing major concerns for human health. Particular attention has centred on rice, as the staple crop for vast Asian populations. Large areas in China and India are affected by Hg-enriched aerial deposition. Studies from the early 2000s on the redistribution of $\mathrm{Hg}$ from aerosols $\left(\mathrm{Hg}^{2+}\right)$ to soil and rice plants in the $\mathrm{Hg}$ polluted area of Guizhou, China, provided useful data on the presence of $\mathrm{Hg}$ in rice grains. Surprisingly, in a soil with 33 to $37 \mathrm{mg}$ inorganic $\mathrm{Hg} \mathrm{kg}^{-1}$, from a sampling point around the Wanshan area, $569 \mu \mathrm{g} \mathrm{kg}^{-1}$ was concentrated in grains, with $145 \mathrm{\mu g} \mathrm{kg}^{-1}$ in the form of $\mathrm{MeHg}$ [117]. Following up those findings, the province of Guizhou was estimated to bear a soil $\mathrm{Hg}$ concentration ranging from 5.1 to $790 \mathrm{mg} \mathrm{kg}^{-1}$. This polluted soil is used to grow other vegetables used for human nutrition [118]. Chinese and baby cabbage, carrot, celery, garlic stem, and Herba houttuyniae root can all accumulate over $30 \mu \mathrm{g} \mathrm{Hg} \mathrm{kg}^{-1}$ (wet weight), with a maximum accumulation of $128 \mu \mathrm{g} \mathrm{Hg} \mathrm{kg}^{-1}$ in the leaves of Chinese cabbage [119]. Vegetal livestock feeding materials, cultivated on Hg-polluted soils are also an important source for $\mathrm{Hg}$ accumulation through the food chain. Studies on ryegrass showed accumulation of $\mathrm{Hg}$ in shoots significantly exceeding regulations [120]. Further assessments of the toxicity and accumulation of $\mathrm{Hg}$ in the edible plant tissues are presented in Table 2. However, few studies on the accumulation of $\mathrm{Hg}$ in crops, vegetables, and fodder plants have been included here because the focus of the review is on phytoremediation.

\subsection{Phytostabilization}

Hg phytostabilization operates mainly in the root region, aiming to decrease the metal bioavailability, to immobilize it within the rhizosphere, to increase adsorption onto roots, to decrease uptake and accumulation in roots, and to maintain negligible translocation [98]. This strategy prevents metal dispersal, with almost no accumulation in the aboveground parts of plants, so that specialised disposal of harvested material is unnecessary. However, this strategy does not truly remediate the substrate by reducing the concentration of $\mathrm{Hg}$. While it would decrease $\mathrm{Hg}$ bioavailability, it would also require constant monitoring of the species' Hg content over time.

The use of woody plants, with annually increasing soil-navigating roots, has been proposed as a method for $\mathrm{Hg}$ phytostabilization in soils. Fast growing Salix spp. have been assessed for their ability to grow under inorganic $\mathrm{Hg}$ contamination and for their capacity to stabilize the metal. Different clones of Salix spp. were investigated for their growth and $\mathrm{Hg}$ accumulation in roots and aboveground tissues. Subsequently, the Hg-tolerant genotype Björn (from S. viminalis $\times$ S. schwerinii E. L. Wolf.) was identified as showing no signs of growth inhibition or water transpiration inhibition when cultivated in solution supplemented with $1 \mu \mathrm{M} \mathrm{Hg}\left(200 \mu \mathrm{g} \mathrm{L}^{-1}\right)$ [121,122]. Moreover, this genotype was able to remove up to $73.9 \%$ of the $\mathrm{Hg}$ from solution and accumulate very high concentrations of the metal in its tissues (up to $216-274 \mathrm{mg} \mathrm{Hg} \mathrm{kg}^{-1} \mathrm{dw}$ ). Based on this Hg tolerance, and on the capacity to retain $80 \%$ of the $\mathrm{Hg}$ taken up within the roots, the genotype was considered a suitable candidate for phytostabilization of $\mathrm{Hg}$. Investigations on its ability to stabilize $\mathrm{Hg}$ within highly contaminated soil ( $30 \mathrm{mg} \mathrm{Hg} \mathrm{kg}^{-1} \mathrm{dw}$ ) were undertaken. 
It showed high capacity to accumulate $\mathrm{Hg}$ in the roots, displaying metal concentrations there of up to $24.90 \mathrm{mg} \mathrm{kg}^{-1} \mathrm{dw}$. This exceeded shoot $\mathrm{Hg}$ concentrations by a factor of 100 [122]. The profile of the $\mathrm{Hg}$ species present in the substrate before cultivation showed that only $0.1 \%$ of $\mathrm{Hg}$ was water soluble. The majority of $\mathrm{Hg}$ was not available for plant uptake as $1.1 \%$ of $\mathrm{Hg}$ was bound to humic and fulvic acids, while the rest of the $\mathrm{Hg}$ ions were retained in complexes. Upon the cultivation of the plants, the only decreases observed in the profile of $\mathrm{Hg}$ in soil were for the exchangeable and humic acid-bound fractions, which were accounted for by root uptake. The cation could have been exchanged for the negative charges on the root cell walls. In conclusion, although the quantity of plant accumulated $\mathrm{Hg}$ was small (only $0.2 \%$ of the total soil $\mathrm{Hg}$ ), this Salix species proved to be a good candidate for the immobilization of the bioavailable form of $\mathrm{Hg}$ in contaminated soil [122].

Salix alba, another willow species of interest, is frequently used as an ornamental tree around and throughout urban areas. Its ability to accumulate $\mathrm{Hg}$ within leaves was assessed in the town of Turda (Romania) [39], where a former chloralkali plant is a constant source of $\mathrm{Hg}$ emissions over the town [37]. The average concentration of $\mathrm{Hg}$ in the leaves was $340 \mathrm{ng} \mathrm{g}^{-1}$, with a maximum value of $4600 \mathrm{ng} \mathrm{g}^{-1}$, recorded for a sample collected from the industrial area. Thermal speciation of the $\mathrm{Hg}$ species present in plant tissue identified the toxin as MeHg. The implications of this study indicate Salix alba leaves as potential sinks for gaseous $\mathrm{Hg}$, with the element being irreversibly contained by conversion into $\mathrm{MeHg}$ [39].

Silene vulgaris, a perennial with high production that is able to colonize metalliferous soils, is another potential $\mathrm{Hg}$ phytostabilizing species. Plants cultivated on two different types of soils ( $\mathrm{pH} 8.55$; organic matter $0.63 \%$ and $\mathrm{pH} 7.07$; organic matter $0.16 \%$ ), supplemented with either 0.6 or $5.5 \mathrm{mg} \mathrm{Hg} \mathrm{kg}^{-1}$ soil, showed no significant decrease in dry biomass compared to plants grown in uncontaminated soil [123]. Plants were evaluated during a complete life cycle of $S$. vulgaris, from February to July and exposed to $\mathrm{Hg}$ in soil as $\mathrm{HgCl}_{2}$. Roots were the main $\mathrm{Hg}$ accumulating organs in both contaminated soils, with significant quantities present in the plants growing in the soil with the higher metal concentration (3.7 and $2.9 \mathrm{mg} \mathrm{kg}^{-1} \mathrm{dw}$ ). Translocation of $\mathrm{Hg}$ was significantly lower in the alkaline soil compared to the neutral soil. The high biomass and the low translocation rates registered in a heavily $\mathrm{Hg}$ contaminated soil $\left(5.5 \mathrm{mg} \mathrm{Hg} \mathrm{kg}^{-1}\right.$ soil) make $S$. vulgaris a noteworthy candidate for phytostabilization trials [123].

Plant species growing on highly Hg-contaminated sites are possible candidates for phytoremediation. Festuca rubra, Poa pratensis, Armoracia lapathifolia, Helianthus tuberosus, and Salix viminalis were cultivated in highly $\mathrm{Hg}$-contaminated soil $\left(261 \mathrm{mg}\right.$ total $\mathrm{Hg} \mathrm{kg}^{-1} \mathrm{dw}$ and $3.1 \mathrm{mg}$ water soluble $\mathrm{Hg} \mathrm{kg}^{-1} \mathrm{dw}$ ) collected from the grounds of an operating chemical factory in Poland [124]. Hg did not significantly affect growth parameters of any of the investigated species in comparison to plants grown in uncontaminated garden soil. Roots were the main storage organs for $\mathrm{Hg}$, with the highest concentrations $\left(5.9 \mathrm{mg} \mathrm{kg}^{-1} \mathrm{dw}\right)$ found in S. viminalis, followed by the two grass species, which had more intricate and deep root networks. F. rubra and P. pratensis and accumulated 3.0 and $2.7 \mathrm{mg} \mathrm{Hg} \mathrm{kg}^{-1}$ dw respectively. $H$. tuberosus and A. lapathifolia were better excluders with only 1.03 and $0.88 \mathrm{mg} \mathrm{Hg} \mathrm{kg}^{-1} \mathrm{dw}$ in their roots. The cell walls of the outer layers of cortical cells and even central cylinder cells were the main binding sites, although $\mathrm{Hg}$ also displayed affinity for parenchyma cell nuclei [124].

Miscanthus $\times$ giganteus $(\mathrm{M} \times \mathrm{G})$ is a promising tool in phytoremediation because of its high biomass and tolerance to a variety of heavy metals $(\mathrm{Cu}, \mathrm{Cd}, \mathrm{Cr}, \mathrm{Pb}, \mathrm{Ni}$ and $\mathrm{Zn})$ [125]. Recently, the hybrid was assessed for its capacity to stabilize both $\mathrm{Hg}$ and $\mathrm{Cd}$ in soils supplemented with low (10 mg Cd kg $\mathrm{mg}^{-1}$ and $\mathrm{mg} \mathrm{Hg} \mathrm{kg}^{-1}$ ) or high $\left(100 \mathrm{mg} \mathrm{Cd} \mathrm{kg}^{-1}\right.$ and $20 \mathrm{mg} \mathrm{Hg} \mathrm{kg}^{-1}$ ) concentrations of metals [126]. During a 3 years experiment, the biomass yield parameters decreased significantly only in the third year for all plants in all treatments compared to the first growth season. The yield of the plants (tonnes $\mathrm{dw}$ ha ${ }^{-1}$ ) grown in low and highly contaminated soils decreased by $36.3 \%$ and $42.7 \%$, respectively compared 
to that of plants grown in unamended soil. By the second year, the mean accumulation of $\mathrm{Hg}$ was statistically significant in the high metal concentration treatment $\left(108.9 \mu \mathrm{g} \mathrm{kg}^{-1}\right)$, while all other treatments and controls had values typically below $30 \mu \mathrm{g} \mathrm{kg}^{-1}$. Generally, the $\mathrm{Hg}$ concentration was low in the aboveground tissues, suggesting that $\mathrm{Hg}$ is retained in the root epidermis and exodermis. Nevertheless, the biomass removal efficiency of plants grown in the highly $\mathrm{Hg}$ contaminated soil was $4.7 \mu \mathrm{g}$ per pot per year $\left(0.79 \mathrm{~g} \mathrm{ha}^{-1}\right)$ in the second year [126].

\subsection{Phytovolatilization}

Phytovolatilization implies that plants facilitate the speciation of $\mathrm{Hg}^{2+}$ to $\mathrm{Hg}^{0}$, concomitant with its transfer from soil into the atmosphere. They should be able to take up $\mathrm{Hg}^{2+}$ in roots and distribute it into other tissues that might possess reductive mechanisms. From this point volatile $\mathrm{Hg}^{0}$ can diffuse outside the cells or into the xylem, eventually escaping the plant tissues either directly or by stomatal transpiration $[98,127]$. The plant biomass would not require special attention as $\mathrm{Hg}$ species are transiently crossing the tissues without accumulation. However, the $\mathrm{Hg}$ species should be bioavailable in the substrate for root uptake, and the release of volatile $\mathrm{Hg}$ forms represents a hazard due to potential redeposition, especially in inland areas with low wind speeds that do not promote atmospheric dilution. Catalytic reduction of $\mathrm{Hg}^{2+}$ followed by $\mathrm{Hg}^{0}$ release into the surroundings occurs naturally in Bacteria, Archaea, and probably in Fungi [128-131]. Plants might be able to reduce $\mathrm{Hg}^{2+}$ by very small imperceptible amounts. Young barley plants can possibly use the available pool of the ascorbate antioxidant system to reduce soluble $\mathrm{Hg}^{2+}$ to $\mathrm{Hg}^{0}$ and thus emit gaseous $\mathrm{Hg}$ from the leaves [132].

Brassica juncea has been cultivated in $\mathrm{HgCl}_{2}$ spiked Hoagland solution in a controlled, gastight chamber system that made it possible for all $\mathrm{Hg}$ to be quantified in all its chemical forms [112] (Table 2). Hg was applied to the growth solution in 0, 0.05, 0.5, 1, 2.5, 5 and $10 \mathrm{mg} \mathrm{L}^{-1}$ concentrations. Even though the higher $\mathrm{Hg}$ concentrations reduced transpiration rates, the total dry biomass accumulated was similar for all plants. Roots were found to concentrate $\mathrm{Hg}$ by 100-270 folds the level in the most contaminated growth solutions, based on dry-weight. Roots also mitigated the volatilization of mercury ions to $\mathrm{Hg}^{0}$, a process that was amplified with increasing concentrations of $\mathrm{Hg}$ in solution. Root-associated algae or bacteria species were probably responsible for the biochemical volatilization. The high efficiency of $\mathrm{Hg}$ removal (95\%) from the water was achieved partly by plant root accumulation, but the greatest factor in this experiment was the increased $\mathrm{Hg}$ volatilization. On 3 field plots, at the site of an abandoned Tui base mine, New Zealand, Moreno et al. used the $\mathrm{Hg}$-tolerant $B$. juncea to extract $\mathrm{Hg}$ from soil and increase the $\mathrm{Hg}$ volatilization process by a combined plant-microbe action [133] (Table 2). It is still not clear how plants facilitate the release of $\mathrm{Hg}$ from soil to the atmosphere. Photoreductive processes or microbial transformation might convert some fractions of the available $\mathrm{Hg}^{2+}$ into $\mathrm{Hg}^{0}$ that would be released through the soil particles or through the plant via the opened stomata. However, phytovolatilization is primarily achieved by the expression of bacterial enzymatic mechanisms in plants, the transgenic approaches being discussed later within this review.

\section{Microorganisms-Assisted Hg Phytoremediation}

Mercury phytoremediation requires plant species to be able to withstand and remove the toxic agent from substrates over extended periods in order to restore the concentration of the metal to an acceptable threshold. Currently, there is still no plant species identified as a $\mathrm{Hg}$ hyperaccumulator, increasing the difficulty of $\mathrm{Hg}$ soil phytoremediation. Application of chemical compound to soils to either reduce or increase $\mathrm{Hg}$ mobility is expensive, unsuitable for large areas and volumes of contaminated soils and potentially damaging for the ecosystem. A promising strategy to overcome these problems involves utilisation of the complex interactions between plants and their associated rhizosphere and/or endophyte microorganisms (bacteria or fungi) (Figure 1). 


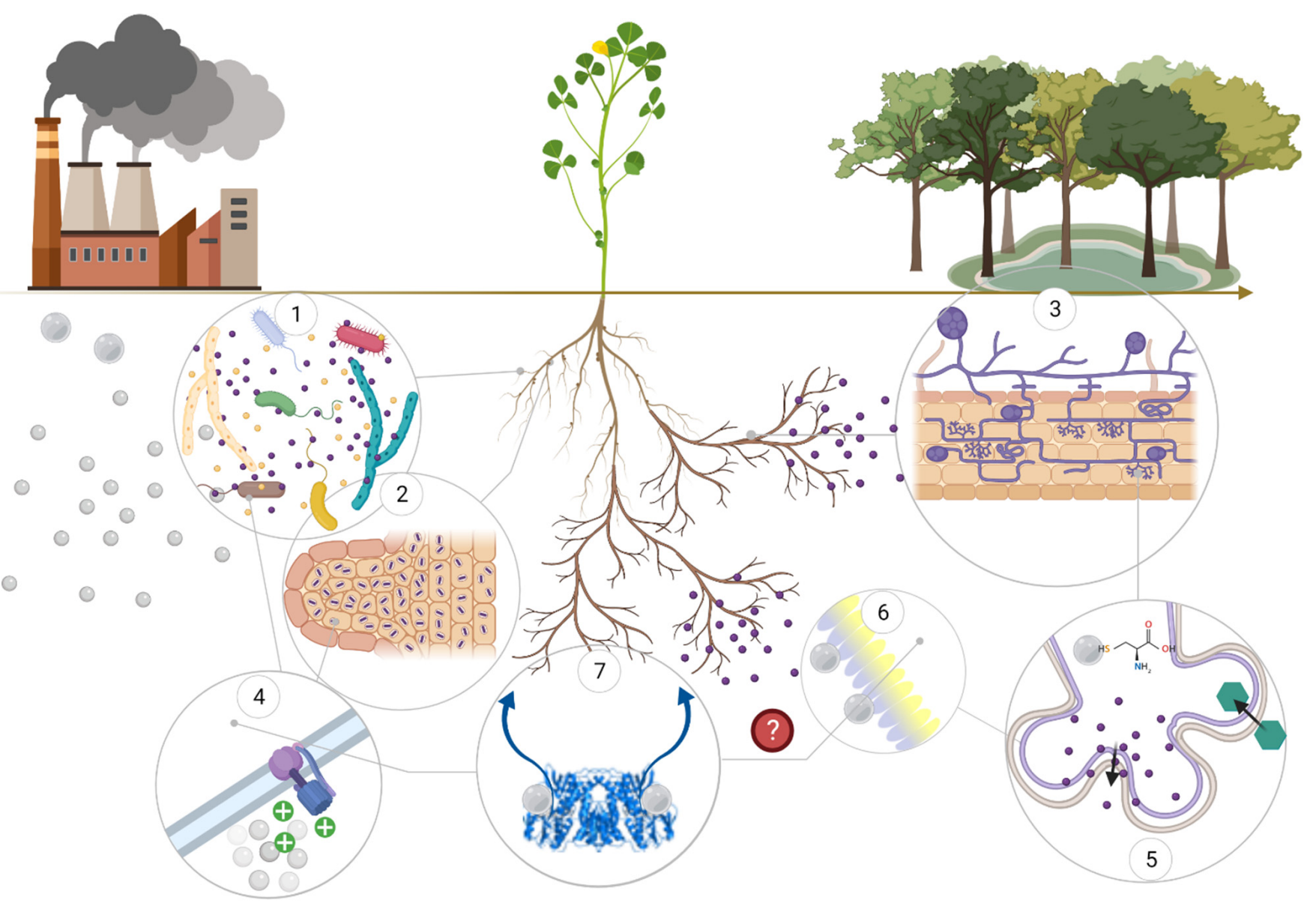

Figure 1. Transition from $\mathrm{Hg}$ contaminated sites towards recovered landscapes, exploiting microbial resistance mechanisms in association with plants (1) Rhizosphere bacteria and fungi providing minerals (N, $\mathrm{P}, \mathrm{K}, \mathrm{Fe})$, growth promoting molecules (hormones, enzymes), and Hg-mobilizing molecules (organic acids, amino acids, phenolic compounds) to the root cells; (2) Rhizobia during nodulation, providing $\mathrm{N}$ to plant root cells, by fixing atmospheric $\mathrm{N}_{2}$; (3) Extended root architecture with tissues colonized by arbuscular mycorrhizal fungi; (4) $\mathrm{Hg}$ mobilization by $\mathrm{H}^{+}$-ATPase protonation; (5) Arbuscular mycorrhizal fungi-plant interface: minerals (purple) are received by the plant cell, while carbohydrates (green) are transferred to fungal cell where $\mathrm{Hg}$ is chelated to cysteine-rich proteins; (6) Hydrophobin monolayer enveloping fungal cell wall, sequestering Hg ions; (7) Reductive volatilization of ionic $\mathrm{Hg}$ by bacteria, and putatively fungal cytosolic mercuric reductase. Created with BioRender.com, accessed on 28 February 2021.

Microorganisms are ubiquitous within soils and the rhizosphere, and establish intricate and poorly understood interactions with plants. These interactions can be either detrimental or beneficial. Exploiting the latter types of relationships could be an avenue to assist phytoremediation using an environmentally acceptable approach. Moreover, plants often utilise localised microorganisms to aid their survival in inhospitable environments. In doing so, they excrete root exudates required by certain microorganisms that in exchange for the provision of essential organic compounds, provide support for plant growth and protection against competitors and predators.

Before fulfilling a role in assisting phytoremediation of $\mathrm{Hg}$-contaminated soils, microorganisms must first overcome the negative selective pressure exerted by the toxic metal. The common mechanisms used by microorganisms to resist heavy metal toxicity include production of organic acids and polysaccharides that chelate metal ions, biosorption within cell walls and envelopes, intracellular accumulation buffered with cysteine-rich proteins, vacuolar sequestration and chemical transformation [134,135]. Microorganisms are able to modulate $\mathrm{Hg}$ speciation in soil by activating specific molecular mechanisms, or by altering the microenvironmental conditions. It has been suggested that 
sulphur-amino acid-decomposing bacteria within the rhizosphere of Helianthus tuberosus and Armoracia lapathifolia growing in Hg-contaminated soil immobilize $\mathrm{Hg}$ within soil as $\mathrm{HgS}$, by means of sulphur release. Thus, bioavailability of $\mathrm{Hg}$, and consequently root uptake, are reduced [124]. Hg immobilization in soil protects plants against toxic concentrations of $\mathrm{Hg}$, allowing revegetation of $\mathrm{Hg}$-contaminated areas. However, the metal persists in the substrate and continues to pose a potential risk. Hence, to achieve removal of the contaminant via plant uptake, $\mathrm{Hg}$-mobilizing bacterial mechanisms have been considered in the context of assisted $\mathrm{Hg}$ phytoextraction.

Mechanisms that enable microorganisms to release $\mathrm{Hg}^{2+}$ from complexed forms in soil, increasing its bioavailability for plants, include $\mathrm{H}^{+}$-ATPases protonation, organic acids and siderophore secretion, and chemical transformation $[134,136]$. The ability of bacteria to interfere with $\mathrm{Hg}$ cycling, by methylation, demethylation, transport, and reduction of $\mathrm{Hg}$ compounds, is encoded under the mer operon, the cluster of specific Hg-resistance mechanisms. The emblematic element of mer operon is mer $A$, encoding for mercuric reductase, a flavin-containing disulfide oxidoreductase, that achieves $\mathrm{Hg}^{2+}$ detoxification by reducing it to $\mathrm{Hg}^{0}$ that can then diffuse outside the cell [128]. In addition to MerA, which enables narrow-spectrum $\mathrm{Hg}$ resistance, the enzyme organomercurial lyase, encoded by the $m e r B$ gene is present in broad-spectrum $\mathrm{Hg}$-resistance. The enzyme cleaves the $\mathrm{C}-\mathrm{Hg}$ bond in organomercurial species by a protonolytic attack, enabling further $\mathrm{Hg}^{2+}$ reduction to be conducted by mercuric reductase [128]. Extensively, other components of the mer operon are merT, merP, merC, encoding for transport proteins, and merR and merD, which encode for regulatory elements [128]. The increased mobility and bioavailability of $\mathrm{Hg}$ in soil, mediated by bacterial processes, would facilitate plant uptake, leading to improved phytoextraction, while $\mathrm{Hg}^{2+}$ volatilization would augment the overall process.

The fundamental trait required in phytoextraction is increased plant biomass, with a significant amount of $\mathrm{Hg}$ accumulated within tissues without impairing plant growth. Mercury adversely affects seedling and root development in non-tolerant plants, photosynthesis efficiency and metabolic homeostasis, leading to a reduction in plant mass. However, even Hg-tolerant plants that might be useful in phytoremediation exhibit similar responses when exposed to toxic $\mathrm{Hg}$ concentrations in soil. Some of the plant-associated microorganisms, including bacteria and fungi, can promote plant growth and thus act as important contributors to plant adaptation to environmental stress caused by heavy metal contaminants. These microorganisms, collectively named plant growth promoting microorganisms (PGPMs), can assist plant growth and reduce metal toxicity either by aiding the acquisition of essential mineral nutrients or by restraining the acquisition of nonessential or toxic minerals or substances. Plant partnerships with Hg-tolerant PGPMs can enhance germination, survival and growth in Hg-contaminated sites. Nevertheless, some microorganisms are able to induce plant defence mechanisms against pathogens and thus, indirectly increase plant fitness and survival [137-139].

Another desirable trait in phytoremediation, that is significant especially for largescale contaminated areas, is the ease of plant establishment. Sowing seeds should be a suitable approach for phytoremediation of open fields, rather than using plantlets, which are costly to grow, time-consuming to plant, and may have a low planting success rate. Accompanying appropriate microbial inoculums could provide crucial support for plants at all developmental stages, from seed to maturity, against the abiotic stress of the toxic element.

The success of microbe-assisted phytoremediation depends on two main effects that microorganisms can exert within the rhizosphere. Firstly, the type and quantity of molecules secreted by PGPMs must confer a survival advantage to relevant plant species under stressful conditions. Secondly, microorganisms should help to increase metal bioavailability, solubility and accumulation in plants, when decontamination rather than stabilization is the aim. 


\subsection{Bacteria-Assisted Hg Phytoremediation}

Plant growth-promoting bacteria (PGPB) comprise a heterogeneous group of prokaryotes inhabiting diverse ecological niches, including rhizosphere free-living (rhizobacteria), root nodule inhabiting (rhizobia) or plant interior tissue-inhabiting (endophytes) species. PGPB are able to stimulate plant growth, acting as biofertilizers, phytostimulators, bioalleviators, biopesticides, and biomodifiers [138,140]. Exchanges between PGPB and associated plant species facilitate survival and growth of both partners under toxic metal stress. Bacterial mechanisms that promote plant growth and protection against phytopathogens are numerous, and often not thoroughly characterized. In general, PGPB provide valuable nutrients (e.g., fixed $\mathrm{N}, \mathrm{Fe}, \mathrm{P}$ ), signals for induction of systemic resistance, e.g., volatile organic compounds, hormones (e.g., abscisic acid, ethylene, jasmonate, cytokinins, gibberellins, indole-3-acetic acid (IAA)), enzymes (e.g., 1-aminocyclopropane1-carboxylate (ACC) deaminase, chitinases, cellulases, proteases, lipases), antibiotics or siderophores $[138,140,141]$.

\subsubsection{Rhizobial Associations}

Research on the Hg-plants-bacteria triad has mainly been focused on assessing the potential of $\mathrm{Hg}$ removal from soil, upon association between plants that are often indigenous to contaminated sites, and symbiotic bacteria. Examination of the potential use of legume-rhizobia associations that are native to contaminated sites, is a pragmatic and practical strategy for $\mathrm{Hg}$ phytoremediation. Legume-rhizobia compatibilities are already settled and, as rhizobia sustain plant growth, they increase plant ability to cope with $\mathrm{Hg}$ stress. In the Almadén mining district in Spain, which is contaminated mainly with $\mathrm{Hg}$, native vegetation, such as Trifolium spp. and Medicago spp., have established specific associations with beneficial Rhizobium leguminosarum bv. trifolii, and Sinorhizobium (Ensifer) medicae respectively [142]. Distinct bacterial isolates showed wide phenotypic diversity in terms of $\mathrm{Hg}$, $\mathrm{pH}$ and salt tolerance, and phosphate solubilization, but no siderophore production [142]. These findings highlight the taxonomic selectivity that plants employ when establishing microbial associations, but the lack of perception of $\mathrm{Hg}$-tolerant strains. Lupinus albus L. plants were able to nodulate, to accumulate about $370 \mathrm{mg} \mathrm{Hg} \mathrm{kg}^{-1}$ in roots, and about $360 \mathrm{mg} \mathrm{Hg} \mathrm{kg}^{-1}$ in nodules, and to maintain constant levels of photosynthetic pigments, when inoculated with Hg-tolerant Bradyrhizobium canariense L-7AH strain, but not with the Hg-sensitive strain L-3, both isolated from the Almadén mining site soil, in substrate containing up to $102 \mathrm{mg} \mathrm{Hg} \mathrm{kg}^{-1}$ [41]. However, the resistance mechanisms of these isolates are not understood, as attempts to detect the mer operon elements were unsuccessful [143].

\subsubsection{Non-Rhizobial Associations}

The possibility of non-rhizobial, but $\mathrm{Hg}$-resistant isolates being used to aid in $\mathrm{Hg}$ removal has been investigated in recent years. A Hg-reducing bacterium, Photobacterium sp. strain MELD1, a symbiont from the rhizosphere of Phragmites australis plants, that is native to Hg- and other heavy metal-contaminated sites, showed promising phytoextraction potential. Vigna unguiculata ssp. sesquipedalis inoculated with Photobacterium sp. and cultivated in contaminated soil (on average $27 \mathrm{mg} \mathrm{Hg} \mathrm{kg}^{-1}$ ), showed increased root length $(11 \%)$, seed number $(33 \%)$, leaf number $(54 \%), \mathrm{Hg}$ uptake in roots $(25 \%)$, and decreased $\mathrm{Hg}$ content in aerial organs (55\%) in comparison to the uninoculated control [42]. Two heavy metal-resistant rhizobacteria, Brevundimonas diminuta SF-S1-5 and Alcaligenes faecalis SF-S1-60, applied individually, assisted Scirpus mucronatus growth in sand containing a mixture of $100 \mathrm{mg} \mathrm{Pb} \mathrm{kg}^{-1}$ and $1 \mathrm{mg} \mathrm{Hg} \mathrm{kg}^{-1}$ over 42 days. The presence of bacteria enhanced phytoaccumulation relative to the uninoculated plants, by up to 650 and $320 \mathrm{mg} \mathrm{Pb} \mathrm{kg}^{-1}$ and up to 7.5 and $2.4 \mathrm{mg} \mathrm{Hg} \mathrm{kg}^{-1}$ in roots and shoots respectively [144]. Growth and $\mathrm{Hg}^{2+}$ uptake capacities were improved in Salvinia natans and Lemna minor grown in aqueous solution containing $0.3 \mathrm{mg} \mathrm{Hg}\left(\mathrm{NO}_{3}\right)_{2} \mathrm{~L}^{-1}$, by the presence of three strains of epiphytic bacteria [145]. Hg-resistant Enterobacter ludwigii and Klebsiella pneumoniae, isolated from 
Alternanthera sessilis and Cyperus esculentus, growing on a Hg-contaminated site individually stimulated growth, lowered proline, malondialdehyde content, and electron leakage in commercial Triticum aestivum seedlings under $75 \mu \mathrm{M} \mathrm{HgCl}_{2}$ in hydroponics [146]. A consortium of $5 \mathrm{Hg} /$ As-resistant bacteria isolated from a $\mathrm{Hg} / \mathrm{As}$ highly contaminated soil, and selected on the basis of their ability to produce IAA, ammonia, exopolysaccharide, biofilm, or to fix $\mathrm{N}_{2}$, was tested in association with thiosulfate, a fertilizer acting as a metal mobilizing agent, for its potential to improve phytoextraction [147]. The inoculum acted synergistically in combination with thiosulfate, enhancing $\mathrm{Hg}$ phytoaccumulation by $35.8 \%$ in Lupinus albus and $44.7 \%$ in Brassica juncea [147].

Multi-metal resistant bacteria, endophytes of Aeschynomene fluminensis and Polygonum acuminatum, sampled from moderately $\mathrm{Hg}$ contaminated soils were investigated for their capacity to assist crop plant species growth under $\mathrm{Hg}^{2+}$ stress. The presence of endophytic bacteria increased Zea mays biomass relative to plants grown in the absence of $\mathrm{Hg}^{2+}$, when grown in soil supplemented with $80 \mathrm{mg} \mathrm{Hg}^{2+} \mathrm{kg}^{-1}$, and reduced the metal concentration in the substrate, by up to $63.19 \%$, mostly due to volatilization [47]. Root and aerial biomass of inoculated Zea mays was $74 \%$ and $26 \%$ higher respectively, with 20 -fold greater $\mathrm{Hg}$ concentrations in roots than in shoots [47]. Inoculation of Zea mays seeds with different rhizosphere bacterial isolates from the above-mentioned plants increased growth in diameter and length of root and shoot by up to $47 \%$ and dry mass by up to $51 \%$ compared to uninoculated plants, when grown in soil containing $40 \mathrm{mg} \mathrm{Hg}^{2+} \mathrm{kg}^{-1} \mathrm{dw}$. Furthermore, the association promoted uptake of up to $923 \mathrm{mg} \mathrm{Hg} \mathrm{kg}^{-1}$ in roots of maize plants, but diminished translocation efficiency to the leaves [46]. These results clearly demonstrate the beneficial effects of certain soil, rhizosphere and endophytic bacteria on $\mathrm{Hg}$ phytoremediation. Although PGP abilities were not consistently assayed across these studies, IAA, $\mathrm{NH}_{3}$ production and $\mathrm{N}_{2}$ fixation were often detected for the investigated bacterial isolates. With respect to $\mathrm{Hg}$ resistance, all isolates were able to grow in the presence of various $\mathrm{Hg}$ concentrations, and some even reduced $\mathrm{Hg}$ concentration in the substrate independently of the presence of plants. However, although it was not examined in all instances, the merA gene was not always detected. Importantly, in addition to sustaining and improving plant growth under toxic conditions, rhizosphere bacteria strongly promote an essential aspect of phytoremediation, namely $\mathrm{Hg}$ uptake by roots. However, the mechanisms by which bacteria promote root $\mathrm{Hg}$ uptake are still poorly understood.

\subsubsection{Bacterial Siderophores, IAA, $\mathrm{NH}_{3}$}

Siderophores are small iron-chelating compounds secreted by both plants and $\mathrm{mi}-$ croorganisms that increase Fe solubility in soil and uptake. There is also evidence that siderophores increase the resistance/tolerance of plants to heavy metal contamination. Thus, the naturally-occurring Ni-resistant microbial community in Thlaspi goesingense at a Ni-contaminated site was able to produce siderophores [148]. The Cd-hyperaccumulator Solanum nigrum benefited from association with its endophyte, Pseudomonas sp. Lk9, which synthesizes siderophores, biosurfactants, and organic acids, increasing $\mathrm{Cd}, \mathrm{Zn}$, and $\mathrm{Cu}$ availability, thus enhancing phytoextraction compared to uninoculated control plants [149]. Bacterial siderophores have been proposed as chelation agents in heavy metal remediation [150], but their interaction with $\mathrm{Hg}$ has scarcely been investigated and results are inconsistent. Induced siderophore synthesis in the presence of $\mathrm{Al}^{3+}, \mathrm{Cd}^{2+}, \mathrm{Cu}^{2+}, \mathrm{Ni}^{2+}$, was demonstrated for three metal-resistant Streptomyces spp., and the binding of $\mathrm{Cd}$ and $\mathrm{Ni}$ to these molecules was confirmed [151]. A stimulatory effect on siderophore production in Pseudomonas aeruginosa strain PAO1 was documented for Cd, but not for $\mathrm{Zn}$ or $\mathrm{Hg}$ [152]. However, a Pseudomonas aeruginosa siderophore-pyoverdine-was shown to chelate $\mathrm{Hg}^{2+}$ extracellularly, forming a complex that is internalized via a cell surface localized transporter [153]. Although the presence of $\mathrm{Hg}$ does not induce siderophore production, the presence of the Hg-siderophore inhibits uptake of the Fe-siderophores complex [153].

It is possible that in the rhizosphere, $\mathrm{Hg}^{2+}$, mobilized by bacterial secreted biosurfactants, organic acid, or by protonation, would chelate to siderophores and eventually cross 
the plants' cells, leading to phytoaccumulation. It has been hypothesized that PGPB might influence root heavy metal uptake by regulating major metal transporter gene families in plants [154], but evidence is lacking in relation to $\mathrm{Hg}$ transport. However, siderophores do not always promote heavy metal uptake in plants, therefore the contrasting effects of siderophore-producing bacteria on heavy metal uptake in plants suggest a plant-dependent metal uptake mechanism [155]. Moreover, not all PGPB are able to produce siderophores. The role of these compounds in relation to $\mathrm{Hg}$ chelation and transfer to root cells is elusive. Nevertheless, they might hold a key for enhancing $\mathrm{Hg}$ root uptake if proven to outcompete Fe.

A detailed phylogenetic tree is presented (Figure 2) for the identified bacterial isolates that have been screened and studied to date, in relationship to their potential for improving Hg phytoremediation and their PGP abilities. The source of isolates included in Figure 2 varies both in terms of the substrate from which they were derived (bulk soil, rhizosphere soil, root nodules, root endophytes), and in the levels of $\mathrm{Hg}$ contamination $[41,42,47,56,147]$. The phylogenetic tree therefore captures bacterial species that are likely to be recruited by plants in Hg-contaminated soils. It also displays the incidence in the bacterial isolates of the $\mathrm{Hg}$ resistance and PGP traits that are relevant for Hg-phytoremediation (Figure 2). The analysis reveals that Proteobacteria phylum has the highest proportion ( $72 \%$ of total isolates) and diversity ( 23 genera), followed by Firmicutes ( $18 \%$ of total isolates with only 5 genera). Proteobacteria is usually the most abundant phylum in uncontaminated soils where the rhizosphere bacterial communities are often represented by Proteobacteria $>$ Actinobacteria $>$ Bacteroidetes $>$ Firmicutes [156]. However, in Hg-contaminated soil, the rhizosphere bacterial community structure exhibits greater species richness and diversity, with the phylum Firmicutes most abundant, and often displaying siderophores, IAA secretion, ammonia production and the mer operon [46].

Further comprehensive investigations of the rhizosphere and endophyte microbiomes and of their PGP abilities, are needed to shed light on the distinct roles played by each taxonomic group in assisting $\mathrm{Hg}$ phytoremediation by candidate plant species. The need for research on PGP traits was highlighted previously, as host plants might select for beneficial traits scattered across different taxonomic groups, rather than for specific taxonomic groups [156]. Moreover, Rhizobiales, such as Bradyrhizobium spp., Rhizobium spp., and Pseudomonadales, such as Acinetobacter spp., Pseudomonas spp., that are included within the tree, represent a universal core microbiome, probably due to their conserved adaptation to the plant environment [156].

Of the bacterial isolates within the tree, $\mathrm{Hg}$ resistance was widespread among Proteobacteria, with minimum inhibitory concentration values spiking above $500 \mu \mathrm{M}$ for about $15 \%$ of the assayed isolates. None of the isolates from other phyla (Firmicutes, Bacteroidetes and Actinobacteria) was able to withstand such an elevated concentration. Of $29 \%$ of the strains that were screened for mer $A$ presence, $45 \%$ were positive, and their tolerance level seems to be correlated with gene presence. It is likely that merA is widespread among bacteria from Hg-contaminated sites, especially for variants encoded by plasmids that enable sharing of this advantageous trait. 


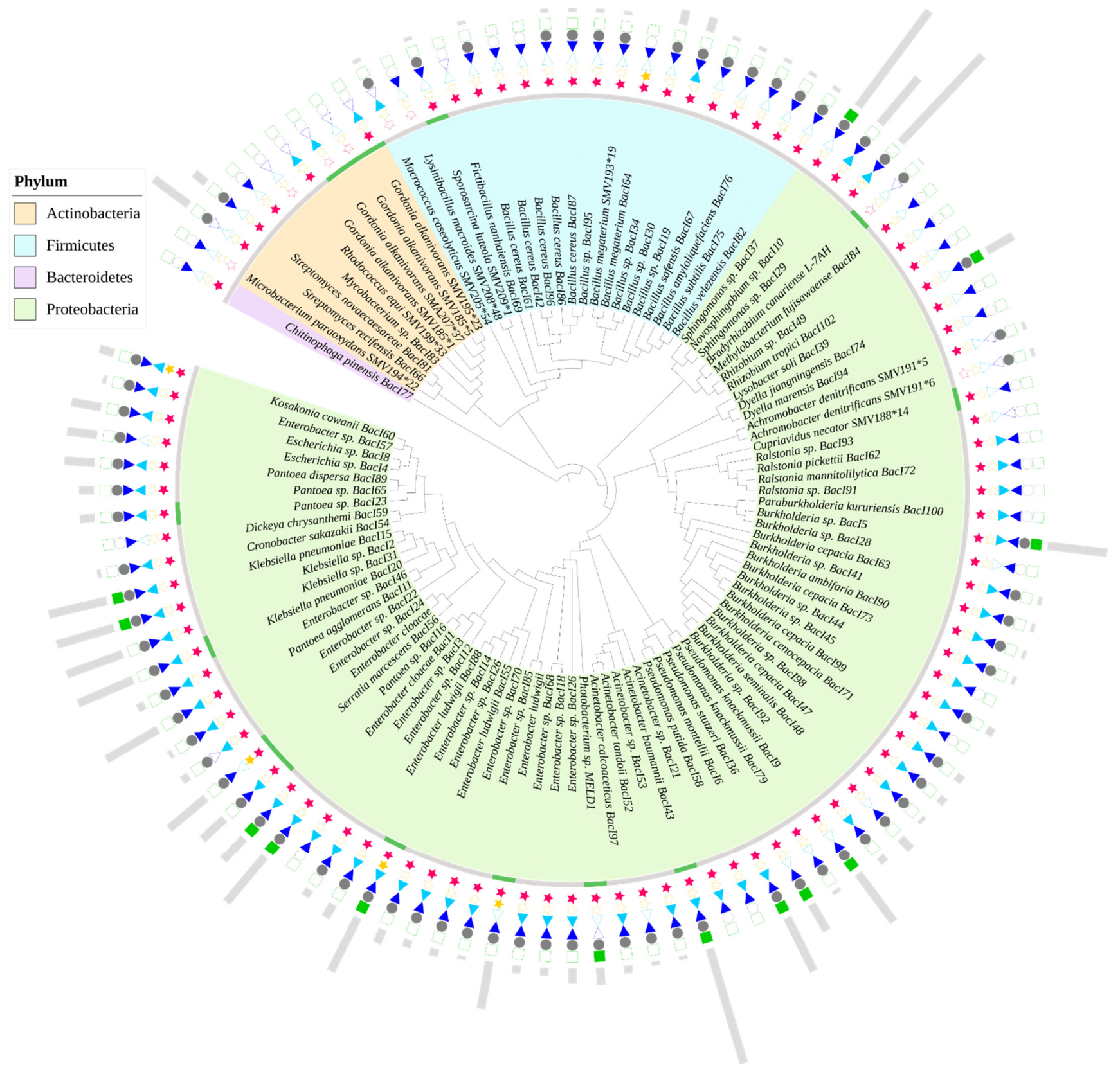

Figure 2. Neighbor-Joining tree, based on Poisson model, of bacterial isolates investigated for their Hg phytoremediation enhancement potential. The full/empty symbols represent the presence/absence of traits relevant to $\mathrm{Hg}$ phytoremediation: red $\star$-IAA production, yellow $\star$ - siderophore production, light blue $\varangle-\mathrm{N}_{2}$ fixation, dark blue $-\mathrm{NH}_{3}$ production, grey $\bullet-\mathrm{Hg}$ resistance, green $\mathbf{\square}-$ merA. The green bands in the grey ring represent the isolates that were tested for their improvement of $\mathrm{Hg}$ phytoremediation, while the external grey bars represent the minimum inhibitory concentration value for $\mathrm{Hg}$. The tree was generated in MEGA X [157], using 16S DNA sequences collected from [41,42,47,56,147], and processed in iTOL [158].

In terms of PGP abilities, IAA and $\mathrm{NH}_{3}$ production are frequent in Proteobacteria and Firmicutes, while $\mathrm{N}_{2}$ fixation and siderophore production are the least commonly detected beneficial traits. Indeed, IAA production is common in soil bacteria. About $80 \%$ of rhizosphere bacteria synthesize this hormone, usually from tryptophane that is released in root exudates $[159,160]$. Bacterial synthesis of IAA is associated with root proliferation when the released IAA quantity is optimum for the associated plant species. However, the positive effects of bacteria-produced IAA on plant phenotype are seen only in conjunction with other PGP mechanisms [161-164], but bacteria-producing IAA 
might confer a significant advantage to plants in $\mathrm{Hg}$ phytoremediation field situations because it stimulates rooting. $\mathrm{NH}_{3}$ production is often associated with $\mathrm{N}_{2}$-fixing bacteria. It may also be produced by ACC deaminase acting on ACC. Therefore, the spectrum of microorganisms able to provide plants with an accessible $\mathrm{N}$ source extends beyond Rhizobia and other non-symbiotic $\mathrm{N}_{2}$-fixing bacteria. Although siderophore-producing ability was screened for in $86 \%$ of the isolates considered, it was a rare trait in bacteria inhabiting plants in Hg-contaminated soils. Conversely, siderophore production was frequently associated with bacteria from heavy metal-contaminated substrates [155]. As plants secrete phytosiderophores, or recruit siderophore-producing bacteria under Felimiting conditions, it is possible that for the source of selected isolates this was not the case.

The bacterial candidates proposed for in situ $\mathrm{Hg}$ assisted-phytoremediation often originate from sites in need of decontamination, in preference to using non-indigenous, potentially invasive species. However, a recent study has shown that PGPB inoculation of Brassica juncea seedlings grown in $\mathrm{Cd}, \mathrm{Cu}, \mathrm{Pb}, \mathrm{Zn}, \mathrm{As}$, Mo-contaminated soil can be beneficial. The non-indigenous inoculum does not significantly alter the composition of the resident bacterial communities over time, but it has also been suggested that it may integrate into these complex communities and intensify their interaction, creating a more efficient community that synergistically resists heavy metals [165]. Nevertheless, plant and bacteria interactions are complex, and the use of non-indigenous species should be carefully considered and assessed before designing large-scale field trials.

\subsection{Fungi}

Mycorrhizal fungi may live inside the plant root cortex, on the root surface, or around the epidermal root cells, and supply plants, by virtue of an extended hyphal network, with phosphates, nitrates or organically bound nutrients that are otherwise unavailable, including exchange of carbohydrates [166-168]. Moreover, when associations are established, they can facilitate resources and chemical signal transfer between different plant individuals through the hyphal network [166].

Similarly to studies of bacteria, studies on fungal-assisted $\mathrm{Hg}$ phytoremediation have focused mostly on symbiotic partners, i.e., arbuscular mycorrhizal fungi (AMF). Interesting findings were revealed involving association of an AMF, Glomus mosseae, with Zea mays in artificially contaminated soil, with $1,2,4 \mathrm{mg} \mathrm{Hg}^{2+} \mathrm{kg}^{-1}$ : the fungus promoted $\mathrm{Hg}$ evaporation and $\mathrm{Hg}$ soil sorption, thus reducing its bioavailability, and subsequently root uptake compared to soils free of inoculum [169]. Similarly, soil inoculation with a commercial arbuscular mycorrhizal formula, containing Rhisophagus irregularis and Funneliformis mosseae propagules contributed to $\mathrm{Hg}$ imobilizatin in soil in combination with humic acid. The AMF formula increased plant growth and $\mathrm{P}$ uptake and reduced $\mathrm{Hg}$ root uptake and translocation in Lactuca sativa, under $10 \mathrm{mg} \mathrm{Hg} \mathrm{kg}^{-1} \mathrm{dw}$ treatment [170]. Commercial arbuscular mycorrhizal formula, represented by Glomus, Entrophospora and Scutellospora genera, improved L. sativa seedlings development and promoted root elongation, even at $100 \mathrm{mg} \mathrm{Hg} \mathrm{kg}^{-1} \mathrm{dw}$ contaminated substrate, relative to uninoculated seedlings [171]. Commercial arbuscular mycorrhizal formulas associated with Lolium perenne, in soil containing $1 \mathrm{mg} \mathrm{Hg}^{2+} \mathrm{kg}^{-1} \mathrm{dw}$, resulted in higher root uptake ( 0.49 vs. $\left.0.12 \mathrm{mg} \mathrm{Hg} \mathrm{kg}^{-1} \mathrm{dw}\right)$, lower translocation ( 0.28 vs. $\left.0.75 \mathrm{mg} \mathrm{Hg} \mathrm{kg}^{-1} \mathrm{dw}\right)$, and lower overall metal removal from substrate (65.8\%), compared to non-inoculated control (75.6\%) [172]. Although these AMF inocula, which are non-indigenous to contaminated sites, stimulate plant growth and protect against $\mathrm{Hg}$ toxicity by reducing its bioavailability, metal removal is not achieved. Glomus sp., isolated from a Hg-polluted site, stimulated $\mathrm{Hg}$ uptake in Zea mays cultivated in soil artificially contaminated with $50 \mathrm{mg} \mathrm{Hg}^{2+} \mathrm{kg}^{-1} \mathrm{dw}$ [44]. The concentration of $\mathrm{Hg}$ in these maize plants was up to $439 \mathrm{mg} \mathrm{kg}^{-1}$, more than twice as high as with a commercial arbuscular mycorrhizal formula and in uninoculated plants. It was hypothesized that fungal metallothioneins (MTs) or PCs could have bound the metal and transferred it to the roots, as the tetrathiol $\mathrm{Hg}$ complexation detected was correlated with the fungus 
samples [44]. In contrast, AMF from a Hg-contaminated site was less effective than a commercial inoculum in terms of promoting plant biomass and photosynthetic pigment content when associated with Zea mays, in soil containing $50 \mathrm{mg} \mathrm{Hg}^{2+} \mathrm{kg}^{-1} \mathrm{dw}$ [173]. Its presence increased the metal's mobility both from soil to roots and within the plant, and impaired mineral uptake [173]. It was concluded that the inoculum native to the contaminated site might not have been compatible with the plant, and that although it was adapted to $\mathrm{Hg}$-contaminated soil, its negative effects on plant growth exceeded any beneficial effects it had on Hg uptake. These studies suggest that mycorrhizal fungi need to have adaptations to $\mathrm{Hg}$ toxicity to promote phytoextraction, and compatibility with the host plant.

Colonization of potential Hg-hyperaccumulator plants with AMF can be a strategy for $\mathrm{Hg}$ phytoremediation. Erato polymnioides individuals, sampled from gold mine soils polluted with $\mathrm{Hg}$, had the highest capacity for $\mathrm{Hg}$ accumulation in roots among the plant species present at the site (Table 2). This could have been due to the high percentage of AMF colonization. Although root-to-leaf $\mathrm{Hg}$ translocation was relatively low, the concentration of $\mathrm{Hg}$ in the aboveground organs was still significantly higher than in the other assessed plant species (Table 2) [103]. Compared to uninoculated plants, Chrysopogon zizanioides cultivated individually with 2 commercial AMF showed improved growth and increased $\mathrm{Hg}$ uptake in 4 weeks, but only in the most contaminated soil (6 $\left.\mathrm{mg} \mathrm{Hg} \mathrm{kg}^{-1} \mathrm{dw}\right)$ [174]. Four highly Hg-tolerant fungal root endophytes, Aspergillus sp., Curvularia geniculata P1, Lindgomycetaceae P87, and Westerdykella sp. P71, applied individually or in combination, increased Aeschynomene fluminensis and Zea mays root dry weight by $43 \%$ to $196 \%$, shoot dry mass by 40 to $59 \%$, and chlorophyll index and $\mathrm{Hg}^{2+}$ accumulation, by $40 \%$ and $34 \%$ respectively. This was mostly due to decreased $\mathrm{Hg}^{2+}$ translocation compared to uninoculated plants [175]. From these studies, it can be assumed that the effects of AMF in $\mathrm{Hg}$ phytoextraction involve increasing plant growth and $\mathrm{Hg}$ root uptake, and lowering $\mathrm{Hg}$ translocation to the shoot. But these effects only occur if the association between the plant and fungus is compatible. How fungi facilitate the transfer of metal from soil into plant tissues is still unclear. Because metal analysis of plant organs can only be done in the presence of the fungal colonizer, it can not be determined whether $\mathrm{Hg}$ has been transferred from the fungus into the plant's cells, or whether it remains bound to the surface of fungal cells, or chelated intracellularly. Nevertheless, it is possible that the fungal network developed within plant tissues, in AMF associations act as a Hg-screen. This would explain the higher $\mathrm{Hg}$ concentrations detected in roots and the tendency for reduced $\mathrm{Hg}$ translocation in such interactions.

Fungi can take up $\mathrm{Hg}^{2+}$ and reduce it to $\mathrm{Hg}^{0}$, as the intracellular presence of metallic $\mathrm{Hg}$ was reported to occur in aquatic environments contaminated with $\mathrm{HgCl}_{2}$ [61]. Fungal MTs and PCs-low molecular weight cysteine-rich proteins involved in heavy metal resistance [176-179] — might chelate cytosolic $\mathrm{Hg}^{2+}$ and sequester it within vacuoles or even relocate it to the plant's root cells. Hydrophobins are proteins of low molecular mass that are unique to fungi, that are rich in cysteine residues, like MTs and PCs, and able to assemble into amphipathic monolayers, with high surfactant activity [180]. These might be involved in $\mathrm{Hg}$ sequestration at the interface with the environment. Puglisi et al. [181] indicated a possible role of these molecules in $\mathrm{Hg}$ resistance, as the transcript level of two hydrophobins was clearly upregulated by the $\mathrm{Hg}$ treatment.

Thus, the repertoire of fungal $\mathrm{Hg}$-resistance mechanisms is diverse and robust, and AMF candidates have already proved beneficial for $\mathrm{Hg}$ phytoremediation. However, understanding of the molecular mechanisms involved in $\mathrm{Hg}$ transfer at the plant-fungus interface is still scarce. Moreover, studies on representatives other than AMF in relation to $\mathrm{Hg}$ phytoremediation are lacking.

\section{Are Transgenic Plants Ready for Hg Phytoremediation?}

Genetic engineering may enable traits promoting phytoremediation to be introduced into suitable recipient plant species. To date, most attempts to achieve this have aimed 
to increase heavy metal accumulation capacity and speed, and tissue specificity for metal uptake, through expression in recipient plants of bacterial genes involved in $\mathrm{Hg}$ detoxification (Figure 3). Most transgenic plants for $\mathrm{Hg}$ phytoremediation are based on the bacterial mer operon, the most effective and widely-studied $\mathrm{Hg}$ resistance mechanism. First attempts were based on Arabidopsis thaliana and Nicotiana tabacum. Encouraging results led to trials being extended to crop species and aquatic species, addressing the problematic bacterial $\mathrm{Hg}$ methylation. However, regulations associated with the hazardous potential of transgenic plants have so far prevented field investigations being carried out.

\begin{tabular}{|c|c|}
\hline \multicolumn{2}{|l|}{ Phytovolatilization } \\
\hline $\begin{array}{l}\mathrm{Hg}^{0} \\
\uparrow \\
\mathrm{Hg}^{2+}\end{array}$ & 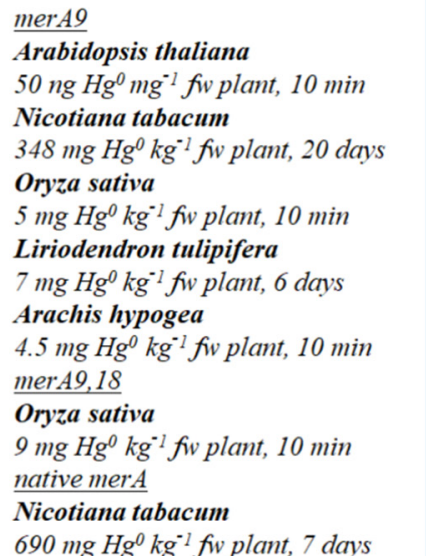 \\
\hline Phytostabilisation & 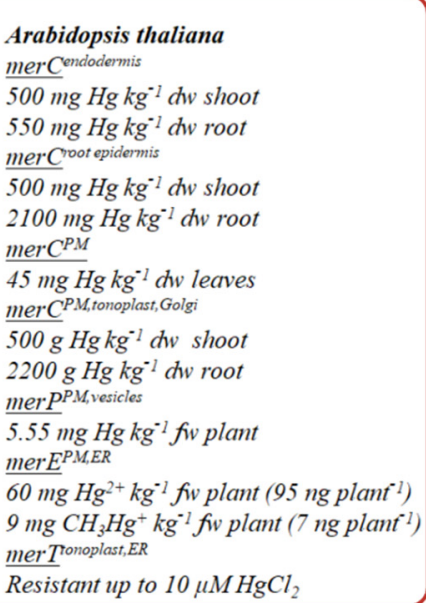 \\
\hline
\end{tabular}

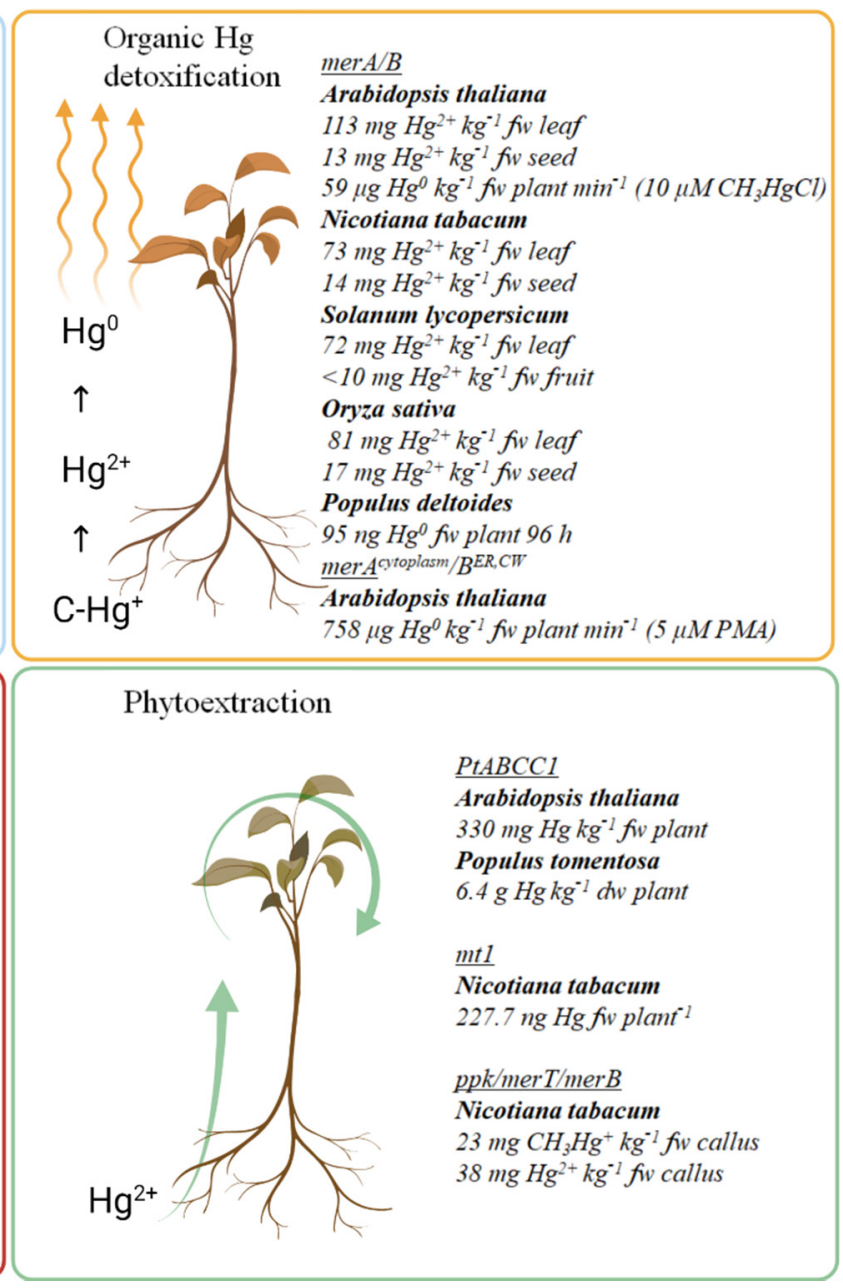

Figure 3. Schematic representation of transgenic plants expressing genes involved in $\mathrm{Hg}$ detoxification reported throughout the literature. The plant species are enlisted under each gene they are transgenic for, and the maximum concentrations or quantities detected in tissues or volatilized are adjacent. The genes were clustered by their phytoremediation outcome: phytovolatilization, which enables the reduction of inorganic $\mathrm{Hg}^{2+}$ to volatile $\mathrm{Hg}^{0}$; organic $\mathrm{Hg}$ detoxification, initiated by dealkylation of organic $\mathrm{Hg}$ compounds by $\mathrm{MerB}$, resulting $\mathrm{Hg}^{2+}$, and followed by reduction to $\mathrm{Hg}^{0}$, if in conjunction with MerA; phytostabilization, which speeds up mercury uptake and its immobilization within root tissues; phytoextraction, which enhances tolerance by augmented Hg-buffering systems; ER—endoplasmic reticulum, CW—cell wall, PM-plasma membrane, $\mathrm{dw}$ - dry weight, fw-fresh weight, PMA — phenylmercury acetate. Created with BioRender.com, accessed on 28 February 2021.

The bacterial native mer $A$ gene encoding for mercuric reductase, isolated from an environmental E. coli plasmid, was successfully integrated into the genome of $N$. tabacum and translated to active MerA [182]. However, the native merA had firstly to be engineered for satisfactory expression of the functional enzyme in plants. Hence, a modified merApe 9 gene was constructed by replacing $9 \%$ of the coding region with nucleotide combinations and codons more common in plants [183]. The transgenic plants obtained were able to 
develop all life stages in medium containing $\mathrm{HgCl}_{2}$ up to $140 \mu \mathrm{M}$, and the MerApe9 mRNA level was correlated with higher rates of $\mathrm{Hg}$ volatilization and resistance. Following this, further engineering of phytovolatilization capacity was carried out. Transgenic lines of Liriodendron tulipifera [184], Nicotiana tabacum [182,185,186], Arachis hypogea [187], Populus deltoides [188], and Oryza sativa [189] showed increased $\mathrm{Hg}$ resistance and volatilization capacity relative to wild type. When assessed, $\mathrm{Hg}$ accumulation was lower in $\mathrm{N}$. tabacum and O. sativa transgenic lines than in wild type plants [186,189], while $\mathrm{Hg}$ volatilization in the N. tabacum transgenic lines was mostly carried out in the root system $[182,185,186]$. This suggests that once $\mathrm{Hg}$ is taken up by the roots it is readily volatilized before moving into aboveground tissues $[182,185,186]$. Grafting experiments of $N$. tabacum wild type stem on merA roots, showed good mobilization of $\mathrm{Hg}$ in roots, followed by stabilization in shoots. It was concluded that this could have been due to accelerated cycling between $\mathrm{Hg}^{2+}$ and $\mathrm{Hg}^{0}$ in merA tissues that delivered $\mathrm{Hg}^{0}$ to the untransformed stems where it was reconverted to $\mathrm{Hg}^{2+}$ and subsequently bound to intracellular chelators [186]. Moreover, among the transgenic lines obtained, which presented different rates of $\mathrm{Hg}$ translocation and accumulation in leaves, sterile lines were identified. These transgenic lines were proposed for safe field application by asexual propagation, since the dispersal of pollen or seeds could not occur [189]. However, phytovolatilization is restricted to the remediation of inorganic $\mathrm{Hg}$ species.

The detoxification mechanism of organic mercury compounds to less harmful $\mathrm{Hg}^{2+}$ and then to $\mathrm{Hg}^{0}$ species-referred to as bacterial broad-spectrum resistance-was sequentially transferred to plants. Arabidopsis thaliana, ecotype RLD, transgenic lines expressing $m e r B$, from plasmid R831b encoding for organomercurial lyase, and $m e r A / B$ were generated. Expression of merB in $A$. thaliana confirmed the resistance phenotype to organic $\mathrm{Hg}$ [190]. Subsequently, the mer $A / B$ lines confirmed that both genes are required for detoxification of organic $\mathrm{Hg}$ to $\mathrm{Hg}^{0}$ [191]. Subsequently, MerB-targeted expression in the endoplasmic reticulum for secretion to the cell wall, in addition to the cytoplasmic MerA, increased the efficiency of processing organic $\mathrm{Hg}$ [192]. The mechanism was also transferred to Populus deltoides, a more suitable candidate for field remediation, which is able to develop large biomass, and a deep root system, making it valuable for long-term usage. Populus deltoides transgenic for mer $A / B$ was superior to wild type and to single gene transgenic lines in terms of resistance and detoxification of organic mercury compounds [193]. The mer $A / B$ constructs were integrated into the $N$. tabacum chloroplast genome, to protect this organelle, which is very sensitive to $\mathrm{Hg}$ toxicity, and to ensure the production of large numbers of transgenes per cell [194]. Organic and inorganic Hg accumulation increased up to 3-fold in roots and 100-fold in shoots relative to untransformed plants, and the transgenic lines attained high tolerance by rapid volatilization. However, the correlation between the mer $A$ and merB transcript levels, and the volatilization capacity were not assayed. Recently, Solanum lycopersicum and Oryza sativa merA/B transgenic lines were proposed as safe crops for remediation of $\mathrm{Hg}$ contaminated soil, since they were able to grow at organic and inorganic $\mathrm{Hg}$ concentrations toxic to the wild type, and to remove $\mathrm{Hg}$ from soil without accumulating it in their leaves, grains and fruits [195]. Thus, transfer of the bacterial broad resistance mechanism to plants can lead to mer $A / B$ transgenic lines capable of decomposing organic $\mathrm{Hg}$ and further volatilizing it to $\mathrm{Hg}^{0}$. However, although presumably organic mercury readily crosses cell membranes due to its lipophilicity as a consequence of a gradient concentration, there was no control over the first step required prior to $\mathrm{Hg}$ detoxification, namely root uptake of $\mathrm{Hg}$ in either organic or inorganic form.

In addition to the $\mathrm{Hg}$ detoxifying enzymes, the mer operon may contain genes expressing $\operatorname{mer} C$, merT, mer $P$ transporters, that internalize $\mathrm{Hg}^{2+}$, and merE that internalizes both $\mathrm{MeHg}$ and $\mathrm{Hg}^{2+}$ in bacteria. Some studies have attempted to increase the speed of phytoextraction by expressing bacterial specific $\mathrm{Hg}$ transporters. Increased inorganic or organic $\mathrm{Hg}$ accumulation was reported for $A$. thaliana transgenic lines for merC, merP, $m e r T$ and merE. The transporters were frequently expressed within the plasma membrane, Golgi apparatus, and vacuolar membrane, providing reduced toxicity compared to the 
wild type. That may be due to vacuolar compartmentalization of the contaminant and chelation of thiol-rich compounds that would decrease ROS production [196-200]. Expression of mer $C$ was achieved in $A$. thaliana in both root epidermis, under the pEpi promoter and endodermis, under SCARECROW promoter, exhibiting higher $\mathrm{Hg}$ accumulation in shoots relative to wild type, and comparable to constitutive overexpressing lines, indicating that tissue-specific expression of transport proteins is sufficient to achieve enhanced $\mathrm{Hg}$ translocation [201,202]. N. tabacum was sequentially engineered with (1) enhanced cellular $\mathrm{Hg}$ sequestration via bacterial ppk, encoding for polyphosphate kinase, the key enzyme in the synthesis of the negative polyP polymer capable of binding metal ions, with (2) merT for accelerated inorganic $\mathrm{Hg}$ uptake, and (3) with merB to extend the spectrum resistance [203-206]. This conceptualization came as a solution to the alarming phenomenon of $\mathrm{Hg}$ volatilization via merA transgenic lines. It effectively provided accelerated uptake of inorganic $\mathrm{Hg}$, detoxification of organic $\mathrm{Hg}$, and enhanced accumulation in plant material from which $\mathrm{Hg}$ could be recovered and recycled [206]. Similarly, $m t 1$, a mouse MT, was integrated into the $N$. tabacum chloroplast genome, generating transgenic lines able to accumulate up to 4.5-fold higher concentrations of inorganic $\mathrm{Hg}$ in all tissues relative to untransformed plants [207]. In addition, overexpression of PtABCC1, a tonoplast-localized ATP-binding cassette $\mathrm{Hg}$-chelate transporter from Populus trichocarpa, proved effective in A. thaliana and Populus tomentosa in promoting growth under $20 \mu \mathrm{M} \mathrm{HgCl}_{2}$ and in increasing $\mathrm{Hg}$ accumulation both in roots and aboveground tissues compared to wild type plants [208]. The strategy of improving the plant tissue tolerance to elevated $\mathrm{Hg}$ levels by constitutive overexpression of mechanisms that buffer $\mathrm{Hg}$ toxicity, gives the possibility of establishing phytoremediation communities in heavily contaminated sites, especially for high biomass producing species. However, there is still concern regarding the secondary pollution that might occur in deciduous trees [208]. Even though woody biomass with high concentrations of $\mathrm{Hg}$ can be harvested and removed, the leaves are also rich in $\mathrm{Hg}$. These require careful disposal too, otherwise they will fall and decompose, returning the $\mathrm{Hg}$ they contain to the soil.

Valuable knowledge has been acquired by engineering plants for $\mathrm{Hg}$ resistance, enabling important steps to be taken towards achieving more successful phytoremediation methods. Phytovolatilization, alone or coupled with organic $\mathrm{Hg}$ detoxification, is effective in $\mathrm{Hg}$ removal from soil, without tissue accumulation, but it would be suitable only for large severely polluted coastal areas, where the volatilized $\mathrm{Hg}^{0}$ can be dispersed by currents and diluted by the atmosphere, before redeposition at safe concentrations [184]. However, in inland fields, it would require the engineering of sealed systems coupled to condensation components that would trap and recover all volatilized $\mathrm{Hg}$ to prevent its atmospheric dispersal. Phytoextraction using transgenic plants capable of degrading and reducing mercury at the root level, with subsequent shoot oxidation and storage, is a preferable option for small areas, irrespective of their location, as Hg-loaded aerial parts are harvestable. Such a strategy would also be ideal for wetlands, where anoxic environment microbiota shift speciation to $\mathrm{MeHg}$, but this assumes the use of wetland transgenic plant species.

\section{Challenges and Perspectives for $\mathrm{Hg}$ Phytoremediation}

Phytoremediation strategies for the decontamination of soils have long been considered more environmentally friendly, less costly and necessitating lower maintenance than engineering-based technologies. They can also be applied to large areas. Phytoremediation of Hg-contaminated sites has been aimed at either extracting, stabilizing or volatilising the metal. However, for phytoremediation of Hg-contaminated soils to become a reliable solution several problems need to be overcome. An important impediment is the high mobility of $\mathrm{Hg}$ between the environmental compartments, due to its ease of speciation. Ionic $\mathrm{Hg}$ from soil is frequently reduced to $\mathrm{Hg}^{0}$, especially by microorganisms, and then emitted into the air. Once in the air, $\mathrm{Hg}^{0}$ is easily dispersed and returned to the soil and plants by deposition, potentially leading to contamination of wider areas, albeit at lower 
concentrations. Plants exposed to aerial $\mathrm{Hg}$ contamination accumulate significant amounts of the metal that are linearly correlated with the concentration of $\mathrm{Hg}$ in the air [209-211]. High biomass vegetation such as willow, planted around the contaminated sites, can act as a buffer trapping the emitted $\mathrm{Hg}$ in its foliage, and thus reduce its dispersal. Indeed the leaves of Salix spp. and other deciduous species return annually, with the mercury they contain, to the soil. However, some of this can be uptaken and immobilized within roots. Nevertheless, (phyto)volatilisation of $\mathrm{Hg}$ should be carefully considered, and as far as possible efforts should be taken to capture gaseous $\mathrm{Hg}$.

Phytostabilization of $\mathrm{Hg}$-contaminated soils is a practical remediation solution because it mainly sequesters $\mathrm{Hg}$ within the roots of plants. It can be successfully applied to heavily contaminated areas that can not be used for agriculture. It requires plant species with a large and extensive root system that can tolerate high concentrations of $\mathrm{Hg}$ and restrict $\mathrm{Hg}$ translocation to aboveground tissues. Good progress has been made in establishing practical programmes for phytostabilisation, with several crops and plant species native to $\mathrm{Hg}$ contaminated soils already investigated. Many plant species that could be used for phytostabilisation might also be safe for seed-consuming birds, as $\mathrm{Hg}$ concentration detected in N. tabacum and O. sativa seeds was under the minimum permissible level [195]. Perennial species with secondary growth that accumulate mass and take up significant $\mathrm{Hg}$ quantities over an extended period are also likely to be suitable candidates for phytostabilization. As deciduous trees might contribute to secondary contamination via decomposition of their leaves each year, evergreen trees would be worth further investigation. Moreover, even though not applicable for crop production, $\mathrm{Hg}$ phytostabilization would produce biomass that, if properly treated, might provide resources to several industries

Phytoextraction of $\mathrm{Hg}$ would be the preferred solution especially for extensive, but only moderately contaminated areas, which might eventually be returned to agricultural use. Efficient phytoextraction would require identification of plant species able to uptake significant amounts of $\mathrm{Hg}$, and further translocate and sequester it in aboveground tissues. For this purpose, identifying $\mathrm{Hg}$ (hyper)accumulator plant species is of utmost importance, since most plant species only have limited $\mathrm{Hg}$ buffering capacity. Furthermore, the $\mathrm{Hg}$ in soil must be in a bioavailable form. Interactions with appropriate microorganisms can aid in $\mathrm{Hg}$ acquisition and even secrete compounds that can augment plant growth. The most beneficial interactions between selected plant species and microorganisms still need further determination. Additionally, mechanised systems for planting and harvesting plant material, and systems for either safe disposal or further processing of contaminated plant material need to be developed.

Importantly, legal environmental and research funding entities need to understand that there is no universal solution for remediating Hg-contaminated sites. The soil properties, the bioavailability of $\mathrm{Hg}$, the interactions between plants and microorganisms and the climate and the environmental conditions will be unique for each site. Use of plant and microorganism species that are not native to a particular site, can lead to undesirable species invasions, creating additional environmental problems. Therefore, use of plants and microorganisms that are pre-adapted to the conditions of particular areas is the ideal to be aspired to. Studies should also focus on identifying the molecular mechanisms of $\mathrm{Hg}$ uptake, distribution and fate in plant species, especially in those identified as potential (hyper)accumulators. Both phytostabilization and phytosequestration would benefit from integration of genes coding for proteins involved in $\mathrm{Hg}$ uptake, transport or sequestration under root- or tissue-specific promoters, and would enhance phytoremediation success over shorter time scales. More research is needed into the molecular interactions between plants and microorganisms. Omics analysis both in plants and microorganisms into their interactions would allow new useful genes and proteins to be identified, and would shed light on these interactions. The knowledge gained would result in the opening of further avenues for using and benefiting from these interactions. Finally, the logistics for efficient implementation of phytoremediation procedures and for recycling or safe disposal of the plant material involved need careful consideration. 


\section{Conclusions}

Reclamation of $\mathrm{Hg}$ contaminated sites is of current interest, as significant areas of land might become productive if remediated. Phytoremediation of $\mathrm{Hg}$-contaminated soils is an emerging strategy because plants handle contaminants without affecting the topsoil, thus preserving, or even improving its fertility through root exudation. Moreover, phytoremediation of sites can provide a low cost and low maintenance solution. To date, no Hg-hyperaccumulator species has been identified although significant progress has been made in identifying plant species that can grow on Hg-contaminated soil. Further assessment of plant species' capacity to accumulate and translocate $\mathrm{Hg}$ when grown alone or in combination with microorganisms on contaminated sites is still necessary. Detailed research is needed to understand the molecular mechanisms underlying the uptake, accumulation, and sequestration of $\mathrm{Hg}$ in plants, and the interactions between plants and their associated microorganisms. Current knowledge of the roles of different microorganism communities in assisting $\mathrm{Hg}$ phytoremediation is limited. We suggest that thorough evaluation of the spatial and temporal distribution of plant-associated microbiomes in Hg-contaminated soils, and the distinctive niches they inhabit throughout plants' developmental stages, would significantly increase understanding of their complex interactions, leading to the phytoremediation concept developing from its currently promising status into a reliable and valuable asset.

Author Contributions: Conceptualization, E.D.T., C.L.V., and D.P.; writing-review and editing, E.D.T., C.L.V., and D.P. All authors have contributed to writing and revising the manuscript. All authors have read and agreed to the published version of the manuscript.

Funding: This work was supported by the Romanian National Authority for Scientific Research and Innovation, CNCS-UEFISCDI, project number PN-III-P2-2.1-PED-2019-5254, contract no. 390PED/2020.

Institutional Review Board Statement: Not applicable for studies not involving humans or animals.

Informed Consent Statement: Not applicable for studies not involving humans.

Acknowledgments: We would like to thank Michael J. Hutchings for his valuable suggestions and improvements on the manuscript.

Conflicts of Interest: The authors declare no conflict of interest.

\section{References}

1. ATSDR Agency for Toxic Substances and Disease Registry. ATSDR's Substance Priority List. Available online: www.atsdr.cdc. gov/spl/index.html (accessed on 28 February 2021).

2. Mason, R.P.; Reinfelder, J.R.; Morel, F.M.M. Bioaccumulation of Mercury and Methylmercury. In Mercury as a Global Pollutant, Proceedings of the Third International Conference Held in Whistler, British Columbia, 10-14 July 1994; Porcella, D.B., Huckabee, J.W., Wheatley, B., Eds.; Springer: Dordrecht, The Netherlands, 1995; pp. 915-921. [CrossRef]

3. Silver, S.; Hobman, J.L. Mercury Microbiology: Resistance Systems, Environmental Aspects, Methylation, and Human Health. In Molecular Microbiology of Heavy Metals; Nies, D.H., Silver, S., Eds.; Springer: Berlin/Heidelberg, Germnay, 2007 ; pp. 357-370. [CrossRef]

4. Skyllberg, U. Chemical Speciation of Mercury in Soil and Sediment. In Environmental Chemistry and Toxicology of Mercury; Liu, G., Cai, Y., O'Driscoll, N., Eds.; John Wiley and Sons, Inc.: Hoboken, NJ, USA, 2011; pp. 219-258. [CrossRef]

5. Kumari, S.; Jamwal, R.; Mishra, N.; Singh, D.K. Recent developments in environmental mercury bioremediation and its toxicity: A review. Environ. Nanotechnol. Monit. Manag. 2020, 13. [CrossRef]

6. Kocman, D.; Wilson, S.J.; Amos, H.M.; Telmer, K.H.; Steenhuisen, F.; Sunderland, E.M.; Mason, R.P.; Outridge, P.; Horvat, M. Toward an Assessment of the Global Inventory of Present-Day Mercury Releases to Freshwater Environments. Int. J. Environ. Res. Public Health 2017, 14, 138. [CrossRef]

7. World Health Organization. Strategic Planning for Implementation of the Health-Related Articles of the Minamata Convention on Mercury; World Health Organization: Geneva, Switzerland, 2019.

8. Cao, L.; Liu, J.; Dou, S.; Huang, W. Biomagnification of methylmercury in a marine food web in Laizhou Bay (North China) and associated potential risks to public health. Mar. Pollut. Bull. 2020, 150, 110762. [CrossRef]

9. Beckers, F.; Rinklebe, J. Cycling of mercury in the environment: Sources, fate, and human health implications: A review. Crit. Rev. Environ. Sci. Technol. 2017, 47, 693-794. [CrossRef] 
10. AMAP/UN Environment. Technical Background Report to the Global Mercury Assessment 2018; Arctic Monitoring and Assessment Programme, Oslo, Norway; UN Environment Programme, Chemicals and Health Branch: Geneva, Switzerland, 2019.

11. Tang, W.-L.; Liu, Y.-R.; Guan, W.-Y.; Zhong, H.; Qu, X.-M.; Zhang, T. Understanding mercury methylation in the changing environment: Recent advances in assessing microbial methylators and mercury bioavailability. Sci. Total Environ. 2020, 714, 136827. [CrossRef]

12. Liu, M.; Zhang, Q.; Cheng, M.; He, Y.; Chen, L.; Zhang, H.; Cao, H.; Shen, H.; Zhang, W.; Tao, S.; et al. Rice life cycle-based global mercury biotransport and human methylmercury exposure. Nat. Commun. 2019, 10, 5164. [CrossRef]

13. Yu, X.; Khan, S.; Khan, A.; Tang, Y.; Nunes, L.M.; Yan, J.; Ye, X.; Li, G. Methyl mercury concentrations in seafood collected from Zhoushan Islands, Zhejiang, China, and their potential health risk for the fishing community: Capsule: Methyl mercury in seafood causes potential health risk. Environ. Int. 2020, 137, 105420. [CrossRef] [PubMed]

14. Wang, Y.; Habibullah-Al-Mamun, M.; Han, J.; Wang, L.; Zhu, Y.; Xu, X.; Li, N.; Qiu, G. Total mercury and methylmercury in rice: Exposure and health implications in Bangladesh. Environ. Pollut. 2020, 265, 114991. [CrossRef] [PubMed]

15. Abeysinghe, K.S.; Qiu, G.; Goodale, E.; Anderson, C.W.N.; Bishop, K.; Evers, D.C.; Goodale, M.W.; Hintelmann, H.; Liu, S.; Mammides, C.; et al. Mercury flow through an Asian rice-based food web. Environ. Pollut. 2017, 229, 219-228. [CrossRef] [PubMed]

16. Broussard, L.A.; Hammett-Stabler, C.A.; Winecker, R.E.; Ropero-Miller, J.D. The Toxicology of Mercury. Lab. Med. 2002, 33, 614-625. [CrossRef]

17. Fisher, J.F.; World Health Organization; International Programme on Chemical Safety. Elemental Mercury and Inorganic Mercury Compounds: Human Health Aspects; World Health Organization: Geneva, Switzerland, 2003.

18. Genchi, G.; Sinicropi, M.S.; Carocci, A.; Lauria, G.; Catalano, A. Mercury Exposure and Heart Diseases. Int. J. Environ. Res. Public Health 2017, 14, 74. [CrossRef]

19. Cappelletti, S.; Piacentino, D.; Fineschi, V.; Frati, P.; D’Errico, S.; Aromatario, M. Mercuric chloride poisoning: Symptoms, analysis, therapies, and autoptic findings. A review of the literature. Crit. Rev. Toxicol. 2019, 49, 329-341. [CrossRef]

20. ATSDR. Minimal Risk Levels (MRLs) for Hazardous Substances. Available online: https://wwwn.cdc.gov/TSP/MRLS/ mrlsListing.aspx (accessed on 18 February 2021).

21. Zahir, F.; Rizwi, S.J.; Haq, S.K.; Khan, R.H. Low dose mercury toxicity and human health. Env. Toxicol Pharm. 2005, 20, 351-360. [CrossRef]

22. Feng, L.; Zhang, C.; Liu, H.; Li, P.; Hu, X.; Wang, H.; Chan, H.M.; Feng, X. Impact of low-level mercury exposure on intelligence quotient in children via rice consumption. Ecotoxicol. Environ. Saf. 2020, 202, 110870. [CrossRef]

23. ATSDR Agency for Toxic Substances and Disease Registry. Toxicological Profile for Mercury; Department of Health and Human Services, Public Health Service: Atlanta, GA, USA, 1999.

24. Rice, K.M.; Walker, E.M.; Wu, M.; Gillette, C.; Blough, E.R. Environmental Mercury and Its Toxic Effects. J. Prev. Med. Public Health 2014, 47, 74-83. [CrossRef]

25. Yang, L.; Zhang, Y.; Wang, F.; Luo, Z.; Guo, S.; Strahle, U. Toxicity of mercury: Molecular evidence. Chemosphere 2020, $245,125586$. [CrossRef]

26. Pirrone, N.; Cinnirella, S.; Feng, X.; Finkelman, R.B.; Friedli, H.R.; Leaner, J.; Mason, R.; Mukherjee, A.B.; Stracher, G.B.; Streets, D.G.; et al. Global mercury emissions to the atmosphere from anthropogenic and natural sources. Atmos. Chem. Phys. 2010, 10, 5951-5964. [CrossRef]

27. Bishop, K.; Shanley, J.B.; Riscassi, A.; de Wit, H.A.; Eklof, K.; Meng, B.; Mitchell, C.; Osterwalder, S.; Schuster, P.F.; Webster, J.; et al. Recent advances in understanding and measurement of mercury in the environment: Terrestrial Hg cycling. Sci. Total Environ. 2020, 721, 137647. [CrossRef]

28. Amos, H.M.; Jacob, D.J.; Streets, D.G.; Sunderland, E.M. Legacy impacts of all-time anthropogenic emissions on the global mercury cycle. Glob. Biogeochem. Cycles 2013, 27, 410-421. [CrossRef]

29. Zhang, Y.; Jaeglé, L.; Thompson, L.; Streets, D.G. Six centuries of changing oceanic mercury. Glob. Biogeochem. Cycles 2014, 28, 1251-1261. [CrossRef]

30. Kocman, D.; Horvat, M.; Pirrone, N.; Cinnirella, S. Contribution of contaminated sites to the global mercury budget. Enviorn. Res. 2013, 125, 160-170. [CrossRef]

31. Reis, A.T.; Rodrigues, S.M.; Araujo, C.; Coelho, J.P.; Pereira, E.; Duarte, A.C. Mercury contamination in the vicinity of a chlor-alkali plant and potential risks to local population. Sci. Total Environ. 2009, 407, 2689-2700. [CrossRef]

32. Fernández-Martínez, R.; Esbrí, J.M.; Higueras, P.; Rucandio, I. Comparison of mercury distribution and mobility in soils affected by anthropogenic pollution around chloralkali plants and ancient mining sites. Sci. Total Environ. 2019, 671, 1066-1076. [CrossRef]

33. Mahbub, K.R.; Bahar, M.M.; Labbate, M.; Krishnan, K.; Andrews, S.; Naidu, R.; Megharaj, M. Bioremediation of mercury: Not properly exploited in contaminated soils! Appl. Microbiol. Biotechnol. 2017, 101,963-976. [CrossRef]

34. Raj, D.; Maiti, S.K. Sources, toxicity, and remediation of mercury: An essence review. Environ. Monit. Assess. 2019, 191, 566. [CrossRef]

35. Suchara, I.; Sucharová, J. Mercury distribution around the Spolana chlor-alkali plant (central Bohemia, Czech Republic) after a catastrophic flood, as revealed by bioindicators. Environ. Pollut. 2008, 151, 352-361. [CrossRef]

36. Grangeon, S.; Guédron, S.; Asta, J.; Sarret, G.; Charlet, L. Lichen and soil as indicators of an atmospheric mercury contamination in the vicinity of a chlor-alkali plant (Grenoble, France). Ecol. Indic. 2012, 13, 178-183. [CrossRef] 
37. Frentiu, T.; Pintican, B.P.; Butaciu, S.; Mihaltan, A.I.; Ponta, M.; Frentiu, M. Determination, speciation and distribution of mercury in soil in the surroundings of a former chlor-alkali plant: Assessment of sequential extraction procedure and analytical technique. Chem. Cent. J. 2013, 7, 178. [CrossRef] [PubMed]

38. Navrátil, T.; Šimeček, M.; Shanley, J.B.; Rohovec, J.; Hojdová, M.; Houška, J. The history of mercury pollution near the Spolana chlor-alkali plant (Neratovice, Czech Republic) as recorded by Scots pine tree rings and other bioindicators. Sci. Total Environ. 2017, 586, 1182-1192. [CrossRef] [PubMed]

39. Esbrí, J.M.; Cacovean, H.; Higueras, P. Usage Proposal of a common urban decorative tree (Salix alba L.) to monitor the dispersion of gaseous mercury: A case study from Turda (Romania). Chemosphere 2018, 193, 74-81. [CrossRef]

40. Zhu, W.; Li, Z.; Li, P.; Yu, B.; Lin, C.-J.; Sommar, J.; Feng, X. Re-emission of legacy mercury from soil adjacent to closed point sources of Hg emission. Environ. Pollut. 2018, 242, 718-727. [CrossRef]

41. Quiñones, M.A.; Ruiz-Díez, B.; Fajardo, S.; López-Berdonces, M.A.; Higueras, P.L.; Fernández-Pascual, M. Lupinus albus plants acquire mercury tolerance when inoculated with an Hg-resistant Bradyrhizobium strain. Plant Physiol. Biochem. 2013, 73, 168-175. [CrossRef] [PubMed]

42. Mathew, D.C.; Ho, Y.-N.; Gicana, R.G.; Mathew, G.M.; Chien, M.-C.; Huang, C.-C. A Rhizosphere-associated symbiont, Photobacterium spp. strain MELD1, and its targeted synergistic activity for phytoprotection against mercury. PLoS ONE 2015, 10, e0121178. [CrossRef] [PubMed]

43. Plociniczak, T.; Sinkkonen, A.; Romantschuk, M.; Sulowicz, S.; Piotrowska-Seget, Z. Rhizospheric Bacterial Strain Brevibacterium casei MH8a Colonizes Plant Tissues and Enhances Cd, Zn, Cu Phytoextraction by White Mustard. Front. Plant Sci. $2016,7,101$. [CrossRef] [PubMed]

44. Kodre, A.; Arčon, I.; Debeljak, M.; Potisek, M.; Likar, M.; Vogel-Mikuš, K. Arbuscular mycorrhizal fungi alter Hg root uptake and ligand environment as studied by X-ray absorption fine structure. Environ. Exp. Bot. 2017, 133, 12-23. [CrossRef]

45. Rahimi Tamandegani, P.; Zafari, D. Evaluation of different Fusarium species-wheat interactions effect on Cd biosorption by wheat seedlings. Int. J. Environ. Sci. Technol. 2019, 16, 1873-1884. [CrossRef]

46. Mariano, C.; Mello, I.S.; Barros, B.M.; da Silva, G.F.; Terezo, A.J.; Soares, M.A. Mercury alters the rhizobacterial community in Brazilian wetlands and it can be bioremediated by the plant-bacteria association. Environ. Sci. Pollut. Res. 2020, 27, 13550-13564. [CrossRef] [PubMed]

47. Mello, I.S.; Targanski, S.; Pietro-Souza, W.; Frutuoso Stachack, F.F.; Terezo, A.J.; Soares, M.A. Endophytic bacteria stimulate mercury phytoremediation by modulating its bioaccumulation and volatilization. Ecotoxicol. Environ. Saf. 2020, $202,110818$. [CrossRef]

48. Reeves, R.D.; Baker, A.J.M.; Jaffré, T.; Erskine, P.D.; Echevarria, G.; van der Ent, A. A global database for plants that hyperaccumulate metal and metalloid trace elements. New Phytol. 2018, 218, 407-411. [CrossRef]

49. Millán, R.; Lominchar, M.A.; Rodríguez-Alonso, J.; Schmid, T.; Sierra, M.J. Riparian vegetation role in mercury uptake (Valdeazogues River, Almadén, Spain). J. Geochem. Explor. 2014, 140, 104-110. [CrossRef]

50. Ekyastuti Wiwik, A.D.; Emi, R. Prospect of indigenous plant species for revegetation in the tailings area of ex community gold mine. Biodiversitas J. Biol. Divers. 2016, 17, 764-768. [CrossRef]

51. Marrugo-Negrete, J.; Marrugo-Madrid, S.; Pinedo-Hernández, J.; Durango-Hernández, J.; Díez, S. Screening of native plant species for phytoremediation potential at a Hg-contaminated mining site. Sci. Total Environ. 2016, 542, 809-816. [CrossRef]

52. Sasmaz, M.; Akgül, B.; Yıldırım, D.; Sasmaz, A. Mercury uptake and phytotoxicity in terrestrial plants grown naturally in the Gumuskoy (Kutahya) mining area, Turkey. Int. J. Phytoremediat. 2016, 18, 69-76. [CrossRef]

53. Xun, Y.; Feng, L.; Li, Y.; Dong, H. Mercury accumulation plant Cyrtomium macrophyllum and its potential for phytoremediation of mercury polluted sites. Chemosphere 2017, 189, 161-170. [CrossRef]

54. Umlaufová, M.; Száková, J.; Najmanová, J.; Sysalová, J.; Tlustoš, P. The soil-plant transfer of risk elements within the area of an abandoned gold mine in Libčice, Czech Republic. J. Environ. Sci. Health Part A 2018, 53, 1267-1276. [CrossRef]

55. Mbanga, O.; Ncube, S.; Tutu, H.; Chimuka, L.; Cukrowska, E. Mercury accumulation and biotransportation in wetland biota affected by gold mining. Environ. Monit. Assess. 2019, 191, 186. [CrossRef] [PubMed]

56. Mello, I.S.; Pietro-Souza, W.; Barros, B.M.; da Silva, G.F.; Campos, M.L.; Soares, M.A. Endophytic bacteria mitigate mercury toxicity to host plants. Symbiosis 2019, 79, 251-262. [CrossRef]

57. Petelka, J.; Abraham, J.; Bockreis, A.; Deikumah, J.P.; Zerbe, S. Soil heavy metal(loid) pollution and phytoremediation potential of native plants on a former gold mine in Ghana. Water Air Soil Pollut. 2019, 230, 267. [CrossRef]

58. Frossard, A.; Hartmann, M.; Frey, B. Tolerance of the forest soil microbiome to increasing mercury concentrations. Soil Biol. Biochem. 2017, 105, 162-176. [CrossRef]

59. Frossard, A.; Donhauser, J.; Mestrot, A.; Gygax, S.; Bååth, E.; Frey, B. Long- and short-term effects of mercury pollution on the soil microbiome. Soil Biol. Biochem. 2018, 120, 191-199. [CrossRef]

60. Wang, L.; Wang, L.-A.; Zhan, X.; Huang, Y.; Wang, J.; Wang, X. Response mechanism of microbial community to the environmental stress caused by the different mercury concentration in soils. Ecotoxicol. Environ. Saf. 2020, 188, 109906. [CrossRef] [PubMed]

61. Hoque, E.; Fritscher, J. A new mercury-accumulating Mucor hiemalis strain EH8 from cold sulfidic spring water biofilms. MicrobiologyOpen 2016, 5, 763-781. [CrossRef] 
62. Figueiredo, N.; Serralheiro, M.L.; Canário, J.; Duarte, A.; Hintelmann, H.; Carvalho, C. Evidence of mercury methylation and demethylation by the estuarine microbial communities obtained in stable $\mathrm{Hg}$ isotope studies. Int. J. Environ. Res. Public Health 2018, 15, 2141. [CrossRef] [PubMed]

63. Pinto, A.P.; Simes, I.; Mota, A.M. Cadmium Impact on Root Exudates of Sorghum and Maize Plants: A Speciation Study. J. Plant Nutr. 2008, 31, 1746-1755. [CrossRef]

64. Montiel-Rozas, M.M.; Madejón, E.; Madejón, P. Effect of heavy metals and organic matter on root exudates (low molecular weight organic acids) of herbaceous species: An assessment in sand and soil conditions under different levels of contamination. Environ. Pollut. 2016, 216, 273-281. [CrossRef] [PubMed]

65. Esteban, E.; Moreno, E.; Peñalosa, J.; Cabrero, J.I.; Millán, R.; Zornoza, P. Short and long-term uptake of Hg in white lupin plants: Kinetics and stress indicators. Environ. Exp. Bot. 2008, 62, 316-322. [CrossRef]

66. Castro, R.; Pereira, S.; Lima, A.; Corticeiro, S.; Válega, M.; Pereira, E.; Duarte, A.; Figueira, E. Accumulation, distribution and cellular partitioning of mercury in several halophytes of a contaminated salt marsh. Chemosphere 2009, 76, 1348-1355. [CrossRef]

67. Carrasco-Gil, S.; Álvarez-Fernández, A.; Sobrino-Plata, J.; Millán, R.; Carpena-Ruiz, R.O.; Leduc, D.L.; Andrews, J.C.; Abadía, J.; Hernández, L.E. Complexation of $\mathrm{Hg}$ with phytochelatins is important for plant $\mathrm{Hg}$ tolerance. Plant Cell Environ. 2011, 34, 778-791. [CrossRef]

68. Chen, J.; Yang, Z.M. Mercury toxicity, molecular response and tolerance in higher plants. BioMetals 2012, 25, 847-857. [CrossRef]

69. Riddle, S.G.; Tran, H.H.; Dewitt, J.G.; Andrews, J.C. Field, laboratory, and X-ray absorption spectroscopic studies of mercury accumulation by water hyacinths. Environ. Sci. Technol. 2002, 36, 1965-1970. [CrossRef]

70. Rajan, M.; Darrow, J.; Hua, M.; Barnett, B.; Mendoza, M.; Greenfield, B.K.; Andrews, J.C. Hg L3 XANES Study of mercury methylation in shredded Eichhornia crassipes. Environ. Sci. Technol. 2008, 42, 5568-5573. [CrossRef] [PubMed]

71. Patty, C.; Barnett, B.; Mooney, B.; Kahn, A.; Levy, S.; Liu, Y.; Pianetta, P.; Andrews, J.C. Using X-ray microscopy and Hg L3 XANES to study $\mathrm{Hg}$ binding in the rhizosphere of Spartina cordgrass. Environ. Sci. Technol. 2009, 43, 7397-7402. [CrossRef]

72. Carrasco-Gil, S.; Siebner, H.; Leduc, D.L.; Webb, S.M.; Millan, R.; Andrews, J.C.; Hernandez, L.E. Mercury localization and speciation in plants grown hydroponically or in a natural environment. Environ. Sci Technol 2013, 47, 3082-3090. [CrossRef]

73. Wang, X.; Tam, N.F.-Y.; Fu, S.; Ametkhan, A.; Ouyang, Y.; Ye, Z. Selenium addition alters mercury uptake, bioavailability in the rhizosphere and root anatomy of rice (Oryza sativa). Ann. Bot. 2014, 114, 271-278. [CrossRef]

74. Kabata-Pendias, A. Trace Elements in Soils and Plants; CRC Press: Boca Raton, FL, USA, 2010.

75. Clemens, S.; Aarts, M.G.M.; Thomine, S.; Verbruggen, N. Plant science: The key to preventing slow cadmium poisoning. Trends Plant Sci. 2013, 18, 92-99. [CrossRef]

76. Ishimaru, Y.; Takahashi, R.; Bashir, K.; Shimo, H.; Senoura, T.; Sugimoto, K.; Ono, K.; Yano, M.; Ishikawa, S.; Arao, T.; et al. Characterizing the role of rice NRAMP5 in manganese, iron and cadmium transport. Sci. Rep. 2012, 2, 286. [CrossRef] [PubMed]

77. Takahashi, R.; Ishimaru, Y.; Senoura, T.; Shimo, H.; Ishikawa, S.; Arao, T.; Nakanishi, H.; Nishizawa, N.K. The OsNRAMP1 iron transporter is involved in Cd accumulation in rice. J. Exp. Bot. 2011, 62, 4843-4850. [CrossRef]

78. Esteban, E.; Deza, M.J.; Zornoza, P. Kinetics of mercury uptake by oilseed rape and white lupin: Influence of Mn and Cu. Acta Physiol. Plant. 2013, 35, 2339-2344. [CrossRef]

79. Regier, N.; Larras, F.; Bravo, A.G.; Ungureanu, V.-G.; Amouroux, D.; Cosio, C. Mercury bioaccumulation in the aquatic plant Elodea nuttallii in the field and in microcosm: Accumulation in shoots from the water might involve copper transporters. Chemosphere 2013, 90, 595-602. [CrossRef] [PubMed]

80. Iglesia-Turiño, S.; Febrero, A.; Jauregui, O.; Caldelas, C.; Araus, J.L.; Bort, J. Detection and quantification of unbound Phytochelatin 2 in plant extracts of Brassica napusgrown with different levels of mercury. Plant Physiol. 2006, 142, 742-749. [CrossRef] [PubMed]

81. Chen, L.; Yang, L.; Wang, Q. In vivo phytochelatins and Hg-phytochelatin complexes in $\mathrm{Hg}$-stressed Brassica chinensis L. Metallomics 2009, 1, 101-106. [CrossRef]

82. Gong, J.-M.; Lee, D.A.; Schroeder, J.I. Long-distance root-to-shoot transport of phytochelatins and cadmium in Arabidopsis. Proc. Natl. Acad. Sci. USA 2003, 100, 10118-10123. [CrossRef]

83. Li, Y.; Heaton, A.C.P.; Carreira, L.; Meagher, R.B. Enhanced tolerance to and accumulation of mercury, but not arsenic, in plants overexpressing two enzymes required for thiol peptide synthesis. Physiol. Plant. 2006, 128, 48-57. [CrossRef]

84. Park, J.; Song, W.-Y.; Ko, D.; Eom, Y.; Hansen, T.H.; Schiller, M.; Lee, T.G.; Martinoia, E.; Lee, Y. The phytochelatin transporters AtABCC1 and AtABCC2 mediate tolerance to cadmium and mercury. Plant J. 2012, 69, 278-288. [CrossRef]

85. Hall, J.L. Cellular mechanisms for heavy metal detoxification and tolerance. J. Exp. Bot. 2002, 53, 1-11. [CrossRef]

86. Hossain, M.A.; Piyatida, P.; da Silva, J.A.T.; Fujita, M. Molecular mechanism of heavy metal toxicity and tolerance in plants: Central role of glutathione in detoxification of reactive oxygen species and methylglyoxal and in heavy metal chelation. J. Bot. 2012, 2012, 872875. [CrossRef]

87. Ortega-Villasante, C.; Rellán-Álvarez, R.; Del Campo, F.F.; Carpena-Ruiz, R.O.; Hernández, L.E. Cellular damage induced by cadmium and mercury in Medicago sativa. J. Exp. Bot. 2005, 56, 2239-2251. [CrossRef]

88. Zhou, Z.S.; Huang, S.Q.; Guo, K.; Mehta, S.K.; Zhang, P.C.; Yang, Z.M. Metabolic adaptations to mercury-induced oxidative stress in roots of Medicago sativa L. J. Inorg. Biochem. 2007, 101, 1-9. [CrossRef]

89. Israr, M.; Sahi, S.; Datta, R.; Sarkar, D. Bioaccumulation and physiological effects of mercury in Sesbania drummondii. Chemosphere 2006, 65, 591-598. [CrossRef]

90. Cho, U.-H.; Park, J.-O. Mercury-induced oxidative stress in tomato seedlings. Plant Sci. 2000, 156, 1-9. [CrossRef] 
91. Malar, S.; Sahi, S.V.; Favas, P.J.C.; Venkatachalam, P. Assessment of mercury heavy metal toxicity-induced physiochemical and molecular changes in Sesbania grandiflora L. Int. J. Environ. Sci. Technol. 2015, 12, 3273-3282. [CrossRef]

92. Heidenreich, B.; Mayer, K.; Sandermann Jr, H.; Ernst, D. Mercury-induced genes in Arabidopsis thaliana: Identification of induced genes upon long-term mercuric ion exposure. Plant Cell Environ. 2001, 24, 1227-1234. [CrossRef]

93. Sävenstrand, H.; Strid, Å. Six genes strongly regulated by mercury in Pisum sativum roots. Plant Physiol. Biochem. 2004, 42, 135-142. [CrossRef]

94. Liu, Z.; Chen, B.; Wang, L.-A.; Urbanovich, O.; Nagorskaya, L.; Li, X.; Tang, L. A review on phytoremediation of mercury contaminated soils. J. Hazard. Mater. 2020, 400, 123138. [CrossRef] [PubMed]

95. Mench, M.; Schwitzguébel, J.-P.; Schroeder, P.; Bert, V.; Gawronski, S.; Gupta, S. Assessment of successful experiments and limitations of phytotechnologies: Contaminant uptake, detoxification and sequestration, and consequences for food safety. Environ. Sci. Pollut. Res. 2009, 16, 876. [CrossRef]

96. Clemens, S.; Palmgren, M.G.; Krämer, U. A long way ahead: Understanding and engineering plant metal accumulation. Trends Plant Sci. 2002, 7, 309-315. [CrossRef]

97. Meagher, R.B.; Heaton, A.C.P. Strategies for the engineered phytoremediation of toxic element pollution: Mercury and arsenic. J. Ind. Microbiol. Biotechnol. 2005, 32, 502-513. [CrossRef] [PubMed]

98. Khalid, S.; Shahid, M.; Niazi, N.K.; Murtaza, B.; Bibi, I.; Dumat, C. A comparison of technologies for remediation of heavy metal contaminated soils. J. Geochem. Explor. 2017, 182, 247-268. [CrossRef]

99. Krämer, U. Metal Hyperaccumulation in Plants. Annu. Rev. Plant Biol. 2010, 61, 517-534. [CrossRef] [PubMed]

100. Kamal, M.; Ghaly, A.E.; Mahmoud, N.; Côté, R. Phytoaccumulation of heavy metals by aquatic plants. Environ. Int. 2004, 29, 1029-1039. [CrossRef]

101. Skinner, K.; Wright, N.; Porter-Goff, E. Mercury uptake and accumulation by four species of aquatic plants. Environ. Pollut. 2007, 145, 234-237. [CrossRef] [PubMed]

102. Marrugo-Negrete, J.; Durango-Hernández, J.; Díaz-Fernández, L.; Urango-Cárdenas, I.; Araméndiz-Tatis, H.; Vergara-Flórez, V.; Bravo, A.G.; Díez, S. Transfer and bioaccumulation of mercury from soil in cowpea in gold mining sites. Chemosphere 2020, 250, 126142. [CrossRef]

103. Chamba, I.; Rosado, D.; Kalinhoff, C.; Thangaswamy, S.; Sánchez-Rodríguez, A.; Gazquez, M.J. Erato polymnioides-A novel Hg hyperaccumulator plant in ecuadorian rainforest acid soils with potential of microbe-associated phytoremediation. Chemosphere 2017, 188, 633-641. [CrossRef]

104. Alcantara, H.J.P.; Doronila, A.I.; Kolev, S.D. Phytoextraction potential of Manihot esculenta Crantz. (cassava) grown in mercuryand gold-containing biosolids and mine tailings. Miner. Eng. 2017, 114, 57-63. [CrossRef]

105. Marrugo-Negrete, J.; Durango-Hernández, J.; Pinedo-Hernández, J.; Olivero-Verbel, J.; Díez, S. Phytoremediation of mercurycontaminated soils by Jatropha curcas. Chemosphere 2015, 127, 58-63. [CrossRef]

106. Smolinska, B.; Rowe, S. The potential of Lepidium sativum L. for phytoextraction of Hg-contaminated soil assisted by thiosulphate. J. Soils Sediments 2015, 15, 393-400. [CrossRef]

107. Lomonte, C.; Doronila, A.I.; Gregory, D.; Baker, A.J.M.; Kolev, S.D. Phytotoxicity of biosolids and screening of selected plant species with potential for mercury phytoextraction. J. Hazard. Mater. 2010, 173, 494-501. [CrossRef]

108. Rodríguez, E.; Peralta-Videa, J.R.; Israr, M.; Sahi, S.V.; Pelayo, H.; Sánchez-Salcido, B.; Gardea-Torresdey, J.L. Effect of mercury and gold on growth, nutrient uptake, and anatomical changes in Chilopsis linearis. Environ. Exp. Bot. 2009, 65, 253-262. [CrossRef]

109. Moreno-Jiménez, E.; Gamarra, R.; Carpena-Ruiz, R.O.; Millán, R.; Peñalosa, J.M.; Esteban, E. Mercury bioaccumulation and phytotoxicity in two wild plant species of Almadén area. Chemosphere 2006, 63, 1969-1973. [CrossRef]

110. Suszcynsky, E.M.; Shann, J.R. Phytotoxicity and accumulation of mercury in tobacco subjected to different exposure routes. Environ. Toxicol. Chem. 1995, 14, 61-67. [CrossRef]

111. Shiyab, S.; Chen, J.; Han, F.X.; Monts, D.L.; Matta, F.B.; Gu, M.; Su, Y. Phytotoxicity of mercury in Indian mustard (Brassica juncea L.). Ecotoxicol. Environ. Saf. 2009, 72, 619-625. [CrossRef]

112. Moreno, F.N.; Anderson, C.W.N.; Stewart, R.B.; Robinson, B.H. Phytofiltration of mercury-contaminated water: Volatilisation and plant-accumulation aspects. Environ. Exp. Bot. 2008, 62, 78-85. [CrossRef]

113. Rodriguez, L.; Rincón, J.; Asencio, I.; Rodríguez-Castellanos, L. Capability of selected crop plants for shoot mercury accumulation from polluted soils: Phytoremediation perspectives. Int. J. Phytoremediat. 2007, 9, 1-13. [CrossRef]

114. Cargnelutti, D.; Tabaldi, L.A.; Spanevello, R.M.; de Oliveira Jucoski, G.; Battisti, V.; Redin, M.; Linares, C.E.B.; Dressler, V.L.; de Moraes Flores, É.M.; Nicoloso, F.T.; et al. Mercury toxicity induces oxidative stress in growing cucumber seedlings. Chemosphere 2006, 65, 999-1006. [CrossRef]

115. Du, X.; Zhu, Y.G.; Liu, W.J.; Zhao, X.S. Uptake of mercury (Hg) by seedlings of rice (Oryza sativa L.) grown in solution culture and interactions with arsenate uptake. Environ. Exp. Bot. 2005, 54, 1-7. [CrossRef]

116. Beauford, W.; Barber, J.; Barringer, A.R. Uptake and distribution of mercury within higher plants. Physiol. Plant. 1977, 39, 261-265. [CrossRef]

117. Horvat, M.; Nolde, N.; Fajon, V.; Jereb, V.; Logar, M.; Lojen, S.; Jacimovic, R.; Falnoga, I.; Liya, Q.; Faganeli, J.; et al. Total mercury, methylmercury and selenium in mercury polluted areas in the province Guizhou, China. Sci. Total Environ. 2003, 304, 231-256. [CrossRef] 
118. Qiu, G.; Feng, X.; Wang, S.; Shang, L. Mercury and methylmercury in riparian soil, sediments, mine-waste calcines, and moss from abandoned $\mathrm{Hg}$ mines in east Guizhou province, southwestern China. Appl. Geochem. 2005, 20, 627-638. [CrossRef]

119. Wang, X.; Li, Y.-F.; Li, B.; Dong, Z.; Qu, L.; Gao, Y.; Chai, Z.; Chen, C. Multielemental contents of foodstuffs from the Wanshan (China) mercury mining area and the potential health risks. Appl. Geochem. 2011, 26, 182-187. [CrossRef]

120. Rodrigues, S.M.; Henriques, B.; Reis, A.T.; Duarte, A.C.; Pereira, E.; Römkens, P.F.A.M. Hg transfer from contaminated soils to plants and animals. Environ. Chem. Lett. 2012, 10, 61-67. [CrossRef]

121. Wang, Y.; Greger, M. Clonal differences in mercury tolerance, accumulation, and distribution in willow. J. Environ. Qual. 2004, 33, 1779-1785. [CrossRef]

122. Wang, Y.; Stauffer, C.; Keller, C.; Greger, M. Changes in Hg fractionation in soil induced by willow. Plant Soil 2005, $275,67-75$. [CrossRef]

123. Pérez-Sanz, A.; Millán, R.; Sierra, M.J.; Alarcón, R.; García, P.; Gil-Díaz, M.; Vazquez, S.; Lobo, M.C. Mercury uptake by Silene vulgaris grown on contaminated spiked soils. J. Environ. Manag. 2012, 95, S233-S237. [CrossRef] [PubMed]

124. Sas-Nowosielska, A.; Galimska-Stypa, R.; Kucharski, R.; Zielonka, U.; Małkowski, E.; Gray, L. Remediation aspect of microbial changes of plant rhizosphere in mercury contaminated soil. Environ. Monit. Assess. 2008, 137, 101-109. [CrossRef] [PubMed]

125. Kerr, J. Phytoremediation of Metal-Contaminated Soils by Industrial Crops. Ph.D. Thesis, University of Glasgow, Glasgow, UK, 2003.

126. Zgorelec, Z.; Bilandzija, N.; Knez, K.; Galic, M.; Zuzul, S. Cadmium and mercury phytostabilization from soil using Miscanthus $\times$ giganteus. Sci. Rep. 2020, 10, 6685. [CrossRef] [PubMed]

127. Tangahu, B.V.; Sheikh Abdullah, S.R.; Basri, H.; Idris, M.; Anuar, N.; Mukhlisin, M. A review on heavy metals (As, Pb, and Hg) uptake by plants through phytoremediation. Int. J. Chem. Eng. 2011, 2011, 939161. [CrossRef]

128. Barkay, T.; Turner, R.; Saouter, E.; Horn, J. Mercury biotransformations and their potential for remediation of mercury contamination. Biodegradation 1992, 3, 147-159. [CrossRef]

129. Barkay, T.; Kritee, K.; Boyd, E.; Geesey, G. A thermophilic bacterial origin and subsequent constraints by redox, light and salinity on the evolution of the microbial mercuric reductase. Environ. Microbiol. 2010, 12, 2904-2917. [CrossRef]

130. Lal, D.; Lal, R. Evolution of mercuric reductase (merA) gene: A case of horizontal gene transfer. Microbiology 2010, 79, 500-508. [CrossRef]

131. Chang, J.; Shi, Y.; Si, G.; Yang, Q.; Dong, J.; Chen, J. The bioremediation potentials and mercury(II)-resistant mechanisms of a novel fungus Penicillium spp. DC-F11 isolated from contaminated soil. J. Hazard. Mater. 2020, 396, 122638. [CrossRef]

132. Battke, F.; Ernst, D.; Halbach, S. Ascorbate promotes emission of mercury vapour from plants. Plant Cell Environ. 2005, 28, 1487-1495. [CrossRef]

133. Moreno, F.N.; Anderson, C.W.N.; Stewart, R.B.; Robinson, B.H. Mercury volatilisation and phytoextraction from base-metal mine tailings. Environ. Pollut. 2005, 136, 341-352. [CrossRef]

134. Gadd, G.M. Microbial influence on metal mobility and application for bioremediation. Geoderma 2004, 122, 109-119. [CrossRef]

135. Gadd, G.M. Metals, minerals and microbes: Geomicrobiology and bioremediation. Microbiology 2010, 156, 609-643. [CrossRef]

136. García-Sánchez, M.; Száková, J. Chapter 12-Biological Remediation of Mercury-Polluted Environments. In Plant Metal Interaction; Ahmad, P., Ed.; Elsevier: Amsterdam, The Netherlands, 2016; pp. 311-334. [CrossRef]

137. Camilios-Neto, D.; Bonato, P.; Wassem, R.; Tadra-Sfeir, M.Z.; Brusamarello-Santos, L.C.C.; Valdameri, G.; Donatti, L.; Faoro, H.; Weiss, V.A.; Chubatsu, L.S.; et al. Dual RNA-seq transcriptional analysis of wheat roots colonized by Azospirillum brasilense reveals up-regulation of nutrient acquisition and cell cycle genes. BMC Genom. 2014, 15, 378. [CrossRef] [PubMed]

138. Ma, Y.; Oliveira, R.S.; Freitas, H.; Zhang, C. Biochemical and molecular mechanisms of plant-microbe-metal interactions: Relevance for phytoremediation. Front. Plant Sci. 2016, 7. [CrossRef]

139. Romero, F.M.; Rossi, F.R.; Gárriz, A.; Carrasco, P.; Ruíz, O.A. A bacterial endophyte from apoplast fluids protects canola plants from different phytopathogens via antibiosis and induction of host resistance. Phytopatholog 2019, 109, 375-383. [CrossRef] [PubMed]

140. Glick, B.R. Plant growth-promoting bacteria: Mechanisms and applications. Scientifica 2012, 2012, 963401. [CrossRef] [PubMed]

141. Naik, K.; Mishra, S.; Srichandan, H.; Singh, P.K.; Sarangi, P.K. Plant growth promoting microbes: Potential link to sustainable agriculture and environment. Biocatal. Agric. Biotechnol. 2019, 21, 101326. [CrossRef]

142. Nonnoi, F.; Chinnaswamy, A.; García de la Torre, V.S.; Coba de la Peña, T.; Lucas, M.M.; Pueyo, J.J. Metal tolerance of rhizobial strains isolated from nodules of herbaceous legumes (Medicago spp. and Trifolium spp.) growing in mercury-contaminated soils. Appl. Soil Ecol. 2012, 61, 49-59. [CrossRef]

143. Ruiz-Díez, B.; Quiñones, M.A.; Fajardo, S.; López, M.A.; Higueras, P.; Fernández-Pascual, M. Mercury-resistant rhizobial bacteria isolated from nodules of leguminous plants growing in high Hg-contaminated soils. Appl. Microbiol. Biotechnol. 2012, 96, 543-554. [CrossRef]

144. Hamzah, A.; Sarmani, S.B.; Yatim, N.I. Phytoremediation of $\mathrm{Pb}$ and $\mathrm{Hg}$ by using Scirpus mucronatus with addition of bacterial inoculums. J. Radioanal. Nucl. Chem. 2015, 304, 151-155. [CrossRef]

145. Sitarska, M.; Traczewska, T.; Filyarovskaya, V. Removal of mercury (II) from the aquatic environment by phytoremediation. Desalination Water Treat. 2016, 57, 1515-1524. [CrossRef]

146. Gontia-Mishra, I.; Sapre, S.; Sharma, A.; Tiwari, S. Alleviation of mercury toxicity in wheat by the interaction of mercury-tolerant plant growth-promoting rhizobacteria. J. Plant Growth Regul. 2016, 35, 1000-1012. [CrossRef] 
147. Franchi, E.; Rolli, E.; Marasco, R.; Agazzi, G.; Borin, S.; Cosmina, P.; Pedron, F.; Rosellini, I.; Barbafieri, M.; Petruzzelli, G. Phytoremediation of a multi contaminated soil: Mercury and arsenic phytoextraction assisted by mobilizing agent and plant growth promoting bacteria. J. Soils Sediments 2017, 17, 1224-1236. [CrossRef]

148. Idris, R.; Trifonova, R.; Puschenreiter, M.; Wenzel, W.W.; Sessitsch, A. Bacterial communities associated with flowering plants of the Ni hyperaccumulator Thlaspi goesingense. Appl. Environ. Microbiol. 2004, 70, 2667-2677. [CrossRef]

149. Chen, L.; Luo, S.; Li, X.; Wan, Y.; Chen, J.; Liu, C. Interaction of Cd-hyperaccumulator Solanum nigrum L. and functional endophyte Pseudomonas sp. Lk9 on soil heavy metals uptake. Soil Biol. Biochem. 2014, 68, 300-308. [CrossRef]

150. Ahmed, E.; Holmström, S.J.M. Siderophores in environmental research: Roles and applications. Microb. Biotechnol. 2014, 7, 196-208. [CrossRef]

151. Dimkpa, C.O.; Svatoš, A.; Dabrowska, P.; Schmidt, A.; Boland, W.; Kothe, E. Involvement of siderophores in the reduction of metal-induced inhibition of auxin synthesis in Streptomyces spp. Chemosphere 2008, 74, 19-25. [CrossRef]

152. Dao, K.-H.T.; Hamer, K.E.; Clark, C.L.; Harshman, L.G. Pyoverdine production by Pseudomonas aeruginosa exposed to metals or an oxidative stress agent. Ecol. Appl. 1999, 9, 441-448. [CrossRef]

153. Braud, A.; Hoegy, F.; Jezequel, K.; Lebeau, T.; Schalk, I.J. New insights into the metal specificity of the Pseudomonas aeruginosa pyoverdine-iron uptake pathway. Environ. Microbiol. 2009, 11, 1079-1091. [CrossRef]

154. Manoj, S.R.; Karthik, C.; Kadirvelu, K.; Arulselvi, P.I.; Shanmugasundaram, T.; Bruno, B.; Rajkumar, M. Understanding the molecular mechanisms for the enhanced phytoremediation of heavy metals through plant growth promoting rhizobacteria: A review. J. Environ. Manag. 2020, 254, 109779. [CrossRef]

155. Rajkumar, M.; Ae, N.; Prasad, M.N.V.; Freitas, H. Potential of siderophore-producing bacteria for improving heavy metal phytoextraction. Trends Biotechnol. 2010, 28, 142-149. [CrossRef]

156. Trivedi, P.; Leach, J.E.; Tringe, S.G.; Sa, T.; Singh, B.K. Plant-microbiome interactions: From community assembly to plant health. Nat. Rev. Microbiol. 2020, 18, 607-621. [CrossRef]

157. Kumar, S.; Stecher, G.; Li, M.; Knyaz, C.; Tamura, K. MEGA X: Molecular Evolutionary Genetics Analysis across Computing Platforms. Mol. Biol. Evol. 2018, 35, 1547-1549. [CrossRef]

158. Letunic, I.; Bork, P. Interactive tree of life (iTOL) v3: An online tool for the display and annotation of phylogenetic and other trees. Nucleic Acids Res. 2016, 44, W242-W245. [CrossRef]

159. Patten, C.L.; Glick, B.R. Bacterial biosynthesis of indole-3-acetic acid. Can. J. Microbiol. 1996, 42, 207-220. [CrossRef]

160. Gamalero, E.; Glick, B.R. Bacterial modulation of plant ethylene levels. Plant Physiol. 2015, 169, 13-22. [CrossRef]

161. Christena, V.-T.; Murthy, B.N.S.; Joseph, O.; Saxena, P.K. Modulation of somatic embryogenesis in hypocotyl-derived cultures of Geranium (Pelargonium x hortorum Bailey) cv Ringo Rose by a Bacterium. In Vitro Cell. Dev. Biol. Plant 1994, 30P, 140-143.

162. Spaepen, S.; Vanderleyden, J.; Remans, R. Indole-3-acetic acid in microbial and microorganism-plant signaling. FEMS Microbiol. Rev. 2007, 31, 425-448. [CrossRef]

163. Spaepen, S.; Vanderleyden, J. Auxin and plant-microbe interactions. Cold Spring Harb. Perspect. Biol. 2011, 3. [CrossRef]

164. Soundar Raju, C.; Aslam, A.; Thangadurai, D.; Sangeetha, J.; Kathiravan, K.; Shajahan, A. Indole acetic acid (IAA) producing endophytic bacteria on direct somatic embryogenesis and plant regeneration of Exacum travancoricum Bedd. Vegetos 2020, 33, 690-702. [CrossRef]

165. Kong, Z.; Wu, Z.; Glick, B.R.; He, S.; Huang, C.; Wu, L. Co-occurrence patterns of microbial communities affected by inoculants of plant growth-promoting bacteria during phytoremediation of heavy metal-contaminated soils. Ecotoxicol. Environ. Saf. 2019, 183, 109504. [CrossRef]

166. van der Heijden, M.G.A.; Martin, F.M.; Selosse, M.-A.; Sanders, I.R. Mycorrhizal ecology and evolution: The past, the present, and the future. New Phytol. 2015, 205, 1406-1423. [CrossRef]

167. Averill, C.; Bhatnagar, J.M.; Dietze, M.C.; Pearse, W.D.; Kivlin, S.N. Global imprint of mycorrhizal fungi on whole-plant nutrient economics. Proc. Natl. Acad. Sci. USA 2019, 116, 23163-23168. [CrossRef]

168. Genre, A.; Lanfranco, L.; Perotto, S.; Bonfante, P. Unique and common traits in mycorrhizal symbioses. Nat. Rev. Microbiol. 2020, 18, 649-660. [CrossRef]

169. Yu, Y.; Zhang, S.; Huang, H. Behavior of mercury in a soil-plant system as affected by inoculation with the arbuscular mycorrhizal fungus Glomus mosseae. Mycorrhiza 2010, 20, 407-414. [CrossRef]

170. Cozzolino, V.; De Martino, A.; Nebbioso, A.; Di Meo, V.; Salluzzo, A.; Piccolo, A. Plant tolerance to mercury in a contaminated soil is enhanced by the combined effects of humic matter addition and inoculation with arbuscular mycorrhizal fungi. Environ. Sci. Pollut. Res. 2016, 23, 11312-11322. [CrossRef]

171. Vargas Aguirre, C.F.; Rivera Páez, F.A.; Escobar Vargas, S. Effect of arbuscular mycorrhizae and mercury on Lactuca sativa (Asteraceae) seedling morpho-histology. Environ. Exp. Bot. 2018, 156, 197-202. [CrossRef]

172. Leudo, A.M.; Cruz, Y.; Montoya-Ruiz, C.; Delgado, M.d.P.; Saldarriaga, J.F. Mercury phytoremediation with Lolium perennemycorrhizae in contaminated soils. Sustainability 2020, 12, 3795. [CrossRef]

173. Debeljak, M.; van Elteren, J.T.; Špruk, A.; Izmer, A.; Vanhaecke, F.; Vogel-Mikuš, K. The role of arbuscular mycorrhiza in mercury and mineral nutrient uptake in maize. Chemosphere 2018, 212, 1076-1084. [CrossRef]

174. Bretaña, B.L.; Salcedo, S.; Casim, L.; Manceras, R. Growth performance and inorganic mercury uptake of Vetiver (Chrysopogon zizanoides Nash) inoculated with arbuscular mycorrhiza fungi (AMF): Its implication to phytoremediation. J. Agric. Res. Dev. Ext. Technol. 2019, 1, 39-47. 
175. Pietro-Souza, W.; de Campos Pereira, F.; Mello, I.S.; Stachack, F.F.F.; Terezo, A.J.; Cunha, C.N.D.; White, J.F.; Li, H.; Soares, M.A. Mercury resistance and bioremediation mediated by endophytic fungi. Chemosphere 2020, 240, 124874. [CrossRef]

176. Kneer, R.; Kutchan, T.M.; Hochberger, A.; Zenk, M.H. Saccharomyces cerevisiae and Neurospora crassa contain heavy metal sequestering phytochelatin. Arch. Microbiol. 1992, 157, 305-310. [CrossRef]

177. Cobine, P.A.; McKay, R.T.; Zangger, K.; Dameron, C.T.; Armitage, I.M. Solution structure of Cu6 metallothionein from the fungus Neurospora crassa. Eur. J. Biochem. 2004, 271, 4213-4221. [CrossRef]

178. Shine, A.M.; Shakya, V.P.S.; Idnurm, A. Phytochelatin synthase is required for tolerating metal toxicity in a basidiomycete yeast and is a conserved factor involved in metal homeostasis in fungi. Fungal Biol. Biotechnol. 2015, 2. [CrossRef] [PubMed]

179. Lorenzo-Gutiérrez, D.; Gómez-Gil, L.; Guarro, J.; Roncero, M.I.G.; Fernández-Bravo, A.; Capilla, J.; López-Fernández, L. Role of the Fusarium oxysporum metallothionein Mt1 in resistance to metal toxicity and virulence. Metallomics 2019, 11, 1230-1240. [CrossRef]

180. Bayry, J.; Aimanianda, V.; Guijarro, J.I.; Sunde, M.; Latgé, J.-P. Hydrophobins-Unique Fungal Proteins. PLoS Pathog. 2012, 8, e1002700. [CrossRef] [PubMed]

181. Puglisi, I.; Faedda, R.; Sanzaro, V.; Lo Piero, A.R.; Petrone, G.; Cacciola, S.O. Identification of differentially expressed genes in response to mercury I and II stress in Trichoderma harzianum. Gene 2012, 506, 325-330. [CrossRef] [PubMed]

182. Shafiul, H.; Md, Z.; Gowher, N.; Srivastava, P.S. Transgenic tobacco plant expressing environmental E. coli merA gene for enhanced volatilization of ionic mercury. J. Microbiol. Biotechnol. 2010, 20, 917-924. [CrossRef]

183. Rugh, C.L.; Wilde, H.D.; Stack, N.M.; Thompson, D.M.; Summers, A.O.; Meagher, R.B. Mercuric ion reduction and resistance in transgenic Arabidopsis thaliana plants expressing a modified bacterial merA gene. Proc. Natl. Acad. Sci. USA 1996, 93, 3182-3187. [CrossRef]

184. Rugh, C.L.; Senecoff, J.F.; Meagher, R.B.; Merkle, S.A. Development of transgenic yellow poplar for mercury phytoremediation. Nat. Biotechnol. 1998, 16, 925-928. [CrossRef] [PubMed]

185. He, Y.K.; Sun, J.G.; Feng, X.Z.; CzakÓ, M.; MÁRton, L. Differential mercury volatilization by tobacco organs expressing a modified bacterial merA gene. Cell Res. 2001, 11, 231-236. [CrossRef]

186. Heaton, A.C.P.; Rugh, C.L.; Wang, N.-J.; Meagher, R.B. Physiological responses of transgenic merA-TOBACCO (Nicotiana tabacum) to foliar and root mercury exposure. Water Air Soil Pollut. 2005, 161, 137-155. [CrossRef]

187. Yang, H.; Nairn, J.O.E.; Ozias-Akins, P. Transformation of peanut using a modified bacterial mercuric ion reductase gene driven by an actin promoter from Arabidopsis thaliana. J. Plant Physiol. 2003, 160, 945-952. [CrossRef]

188. Che, D.; Meagher, R.B.; Heaton, A.C.P.; Lima, A.; Rugh, C.L.; Merkle, S.A. Expression of mercuric ion reductase in Eastern cottonwood (Populus deltoides) confers mercuric ion reduction and resistance. Plant Biotechnol. J. 2003, 1, 311-319. [CrossRef] [PubMed]

189. Heaton, A.C.P.; Rugh, C.L.; Kim, T.; Wang, N.J.; Meagher, R.B. Toward detoxifying mercury-polluted aquatic sediments with rice genetically engineered for mercury resistance. Environ. Toxicol. Chem. 2003, 22, 2940-2947. [CrossRef]

190. Bizily, S.P.; Rugh, C.L.; Summers, A.O.; Meagher, R.B. Phytoremediation of methylmercury pollution: merB expression in Arabidopsis thaliana confers resistance to organomercurials. Proc. Natl. Acad. Sci. USA 1999, 96, 6808-6813. [CrossRef] [PubMed]

191. Bizily, S.P.; Rugh, C.L.; Meagher, R.B. Phytodetoxification of hazardous organomercurials by genetically engineered plants. Nat. Biotechnol. 2000, 18, 213-217. [CrossRef] [PubMed]

192. Bizily, S.P.; Kim, T.; Kandasamy, M.K.; Meagher, R.B. Subcellular targeting of methylmercury lyase enhances its specific activity for organic mercury detoxification in Plants. Plant Physiol. 2003, 131, 463-471. [CrossRef] [PubMed]

193. Lyyra, S.; Meagher, R.B.; Kim, T.; Heaton, A.; Montello, P.; Balish, R.S.; Merkle, S.A. Coupling two mercury resistance genes in Eastern cottonwood enhances the processing of organomercury. Plant Biotechnol. J. 2007, 5, 254-262. [CrossRef]

194. Hussein, H.S.; Ruiz, O.N.; Terry, N.; Daniell, H. Phytoremediation of Mercury and Organomercurials in Chloroplast Transgenic Plants: Enhanced Root Uptake, Translocation to Shoots, and Volatilization. Environ. Sci. Technol. 2007, 41, 8439-8446. [CrossRef]

195. Li, R.; Wu, H.; Ding, J.; Li, N.; Fu, W.; Gan, L.; Li, Y. Transgenic merA and merB expression reduces mercury contamination in vegetables and grains grown in mercury-contaminated soil. Plant Cell Rep. 2020, 39, 1369-1380. [CrossRef]

196. Sasaki, Y.; Hayakawa, T.; Inoue, C.; Miyazaki, A.; Silver, S.; Kusano, T. Generation of mercury-hyperaccumulating plants through transgenic expression of the bacterial mercury membrane transport protein MerC. Transgenic Res. 2006, 15, 615. [CrossRef]

197. Hsieh, J.-L.; Chen, C.-Y.; Chiu, M.-H.; Chein, M.-f.; Chang, J.-S.; Endo, G.; Huang, C.-C. Expressing a bacterial mercuric ion binding protein in plant for phytoremediation of heavy metals. J. Hazard. Mater. 2009, 161, 920-925. [CrossRef]

198. Kiyono, M.; Oka, Y.; Sone, Y.; Nakamura, R.; Sato, M.H.; Sakabe, K.; Pan-Hou, H. Bacterial heavy metal transporter MerC increases mercury accumulation in Arabidopsis thaliana. Biochem. Eng. J. 2013, 71, 19-24. [CrossRef]

199. Sone, Y.; Nakamura, R.; Pan-Hou, H.; Sato, M.H.; Itoh, T.; Kiyono, M. Increase methylmercury accumulation in Arabidopsis thaliana expressing bacterial broad-spectrum mercury transporter MerE. AMB Express 2013, 3, 52. [CrossRef]

200. Xu, S.; Sun, B.; Wang, R.; He, J.; Xia, B.; Xue, Y.; Wang, R. Overexpression of a bacterial mercury transporter MerT in Arabidopsis enhances mercury tolerance. Biochem. Biophys. Res. Commun. 2017, 490, 528-534. [CrossRef]

201. Uraguchi, S.; Sone, Y.; Kamezawa, M.; Tanabe, M.; Hirakawa, M.; Nakamura, R.; Takanezawa, Y.; Kiyono, M. Ectopic expression of a bacterial mercury transporter MerC in root epidermis for efficient mercury accumulation in shoots of Arabidopsis plants. Sci. Rep. 2019, 9, 4347. [CrossRef] 
202. Uraguchi, S.; Sone, Y.; Yoshikawa, A.; Tanabe, M.; Sato, H.; Otsuka, Y.; Nakamura, R.; Takanezawa, Y.; Kiyono, M. SCARECROW promoter-driven expression of a bacterial mercury transporter MerC in root endodermal cells enhances mercury accumulation in Arabidopsis shoots. Planta 2019, 250, 667-674. [CrossRef]

203. Nagata, T.; Kiyono, M.; Pan-Hou, H. Engineering expression of bacterial polyphosphate kinase in tobacco for mercury remediation. Appl. Microbiol. Biotechnol. 2006, 72, 777-782. [CrossRef] [PubMed]

204. Nagata, T.; Ishikawa, C.; Kiyono, M.; Pan-Hou, H. Accumulation of mercury in transgenic tobacco expressing bacterial polyphosphate. Biol. Pharm. Bull. 2006, 29, 2350-2353. [CrossRef]

205. Nagata, T.; Nakamura, A.; Akizawa, T.; Pan-Hou, H. Genetic engineering of transgenic tobacco for enhanced uptake and bioaccumulation of mercury. Biol. Pharm. Bull. 2009, 32, 1491-1495. [CrossRef]

206. Nagata, T.; Morita, H.; Akizawa, T.; Pan-Hou, H. Development of a transgenic tobacco plant for phytoremediation of methylmercury pollution. Appl. Microbiol. Biotechnol. 2010, 87, 781-786. [CrossRef]

207. Ruiz, O.N.; Alvarez, D.; Torres, C.; Roman, L.; Daniell, H. Metallothionein expression in chloroplasts enhances mercury accumulation and phytoremediation capability. Plant Biotechnol. J. 2011, 9, 609-617. [CrossRef]

208. Sun, L.; Ma, Y.; Wang, H.; Huang, W.; Wang, X.; Han, L.; Sun, W.; Han, E.; Wang, B. Overexpression of PtABCC1 contributes to mercury tolerance and accumulation in Arabidopsis and poplar. Biochem. Biophys. Res. Commun. 2018, 497, 997-1002. [CrossRef]

209. De Temmerman, L.; Claeys, N.; Roekens, E.; Guns, M. Biomonitoring of airborne mercury with perennial ryegrass cultures. Environ. Pollut. 2007, 146, 458-462. [CrossRef]

210. De Temmerman, L.; Waegeneers, N.; Claeys, N.; Roekens, E. Comparison of concentrations of mercury in ambient air to its accumulation by leafy vegetables: An important step in terrestrial food chain analysis. Environ. Pollut. 2009, 157, 1337-1341. [CrossRef]

211. Niu, Z.; Zhang, X.; Wang, Z.; Ci, Z. Field controlled experiments of mercury accumulation in crops from air and soil. Environ. Pollut. 2011, 159, 2684-2689. [CrossRef] 